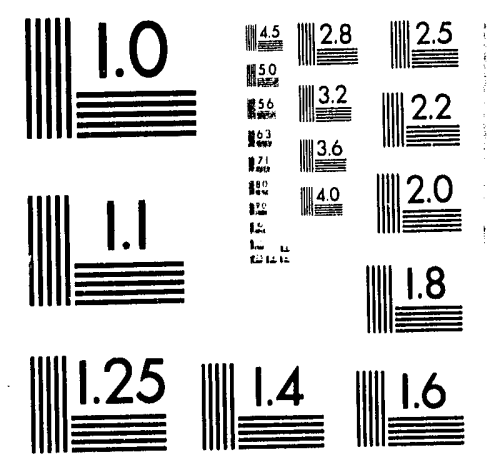



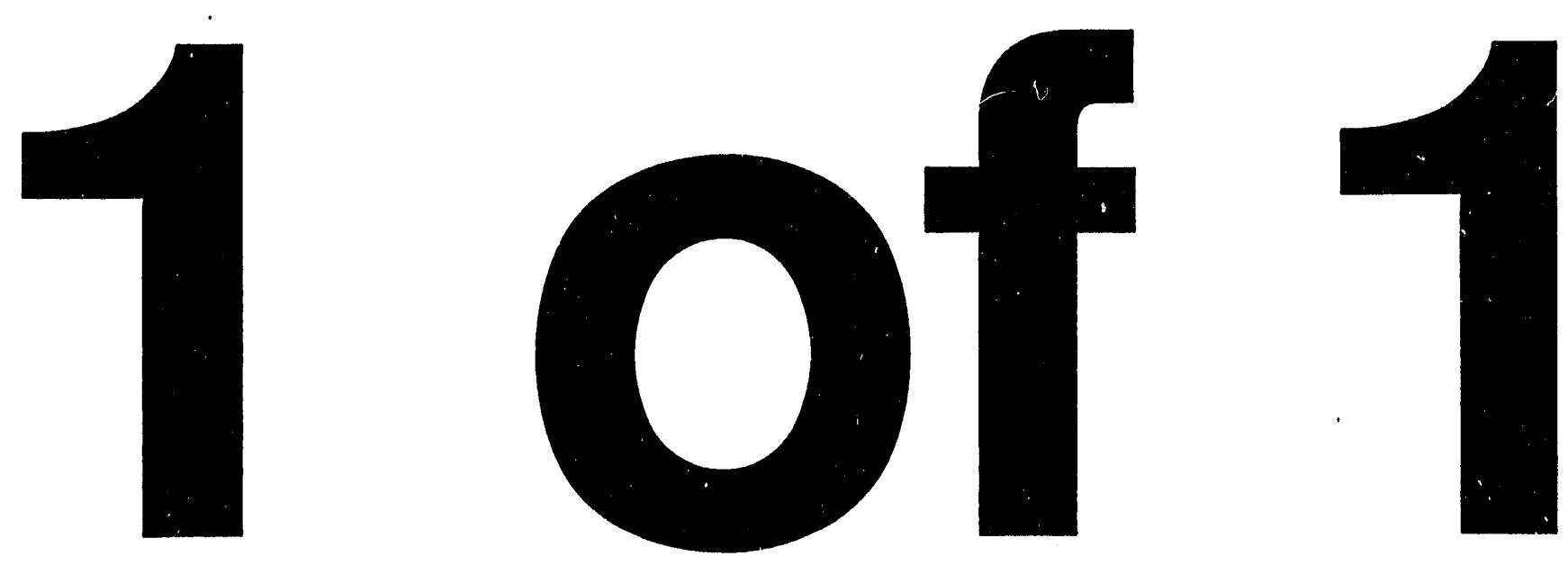


\section{White Bluffs Pickling Acid Cribs Expedited Response Action Proposal}

Date Published

July 1993

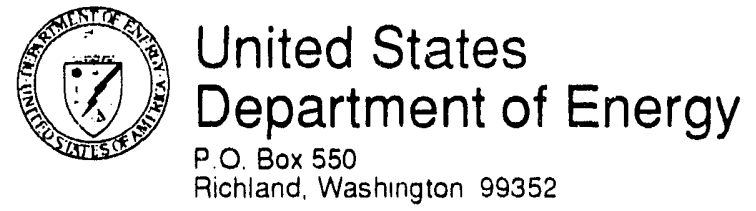

Richland, Washıngton 99352 


\section{CONTENTS}

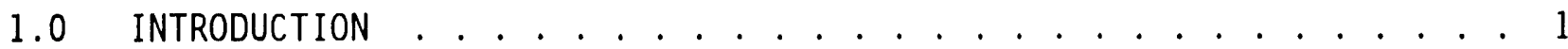

2.0 SITE DESCRIPTION . EHYSICA DESCRIPTION . . . . . . . . . . . 1

2.1 LOCATION AND PHYSICAL DESCRIPTION . . . . . . . . . . . . . . . 1

3.0 CHARACTERIZATION ACTIVITIES . . . . . . . . . . . . . . . . . . . 4

3.1 RADIOLOGICAL SURVEYS . . . . . . . . . . . . . . . . . 4

3.2 GEOPHYSICAL SURVEYS . . . . . . . . . . . . . . . . . . . . 4

3.3 HISTORICAL RESEARCH . . . . . . . . . . . . . . . . . 7

3.4 SAMPLING . . . . . . . . . . . . . . . . . . . . . . . . . 7

4.0 DATA ASSESSMENT . . . . . . . . . . . . . . . . . . . . . . 7

4.1 CONTAMINANTS OF CONCERN . . . . . . . . . . . . . 7

4.2 DATA VALIDATION .................... . . . . . . . . . .

4.3 DATA TABLES . . . . . . . . . . . . . . . . . . . . . . 10

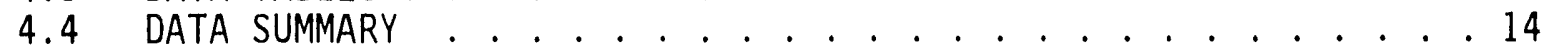

5.0 APPLICABLE OR RELEVANT AND APPROPRIATE REQUIREMENTS . . . . . . . 15

6.0 CONCLUSIONS AND RECOMMENDATIONS . . . . . . . . . . . . 15

7.0 REFERENCES . . . . . . . . . . . . . . . . . . . . . 15

\section{APPENDIX:}

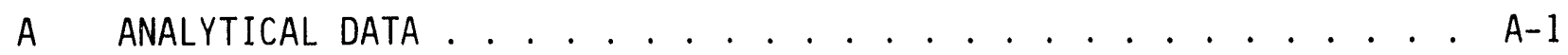

\section{ATTACHMENT :}

1 JOINT LETTER FROM REGULATORS

\section{FIGURES:}

1. Location of the White Bluffs Pickling Acid Cribs .......... 2

2. Location of the 100-IU-2 and 100-IU-5 Operable Units ....... 3

3. GPR Report/Pipe Layout . . . . . . . . . . . . . . . . . . . 5

4. Plan and Sections Through Cribs . . . . . . . . . . . . . . 6

5. Soil Sampling Locations.................. . 9

\section{TABLES:}

1. Soil Sampling Locations and Analyses . . . . . . . . . . . . 8

2. Metals (Reported in $\mathrm{mg} / \mathrm{kg}$ ) . . . . . . . . . . . . . . . 11

3. Anions (Reported in $\mathrm{mg} / \mathrm{kg}$ ) . . . . . . . . . . . . . . 13

4. Risk Evaluation for Chemicals with Concentrations Above Background . 14 
DOE/RL-93-48, Rev. 0 
DOE/RL-93-48, Rev. 0

\subsection{INTRODUCTION}

The U.S. Environmental Protection Agency (EPA) and Washington State Department of Ecology (Ecology) recommended in a letter dated March 4, 1992 (Attachment 1) that the U.S. Department of Energy (DOE) prepare an expedited response action (ERA) for the White Bluffs Pickling Acid Cribs Site (Location, Figure 1). The lead regulatory agency for this ERA is the EPA, with Ecology providing support. The ERA will follow applicable sections of 40 CFR 300 , Subpart E (EPA 1990); the Hanford Federal Facility Agreement and Consent order (Part 3, Article XIII, Section 38) (Ecology et a1. 1989); the Comprehensive Environmental Response, Compensation, and Liability Act of 1980 (CERCLA); the Resource Conservation and Recovery Act of 1976 (RCRA); and the State of Washington Model Toxics Control Act (MTCA).

The goal of this ERA is to reduce the potential of any residual contaminant migration from the cribs to the soil column and groundwater. The cribs are the only waste site within the 100-IU-5 operable unit (Figure 2). Since the operable unit is surrounded by other waste units, tracing the potential groundwater contamination from the 100-IU-5 operable unit for this ERA would not be effective. Groundwater will be investigated with the 100-IU-2 operable unit.

This ERA proposal presents the characterization data from the site investigations conducted in November of 1992. This information is evaluated to present the best method for reducing potential of contaminant migration from the disposal unit, ensuring both protection of human health and the environment.

The ERA proposal will undergo a public review. EPA and Ecology will issue an Action Agreement Memorandum after comment resolution. This Action Memorandum may authorize implementation of the ERA proposal's recommended alternative. The ERA may also provide a No Further Action Interim Record of Decision (IROD) of the 100-IU-5 operable unit.

\subsection{SITE DESCRIPTION}

\subsection{LOCATION AND PHYSICAL DESCRIPTION}

The White Bluffs Pickling Acid Cribs Site is the only waste site identified in the 100-IU-5 operable unit. It is located south of the White Bluffs Town Site, in the 600 Area of the Hanford Site. The White Bluffs Area was the location of construction activities during the early days at Hanford. After construction, most of the facilities at the White Bluffs site were torn down. Other than the historical information obtained in the Hanford Site Waste Management Unit Reports (DOE-RL 1992), little is known about activities conducted at the site in its early years. It is believed that the cribs received waste streams (primarily acid etch solutions) from a pipe fabrication facility operating sometime between 1943 and 1959 . The pipe fabrication facility is suspected to have been located northeast of the cribs. 
Figure 1. Location of the White Bluffs Pickling Acid Cribs.

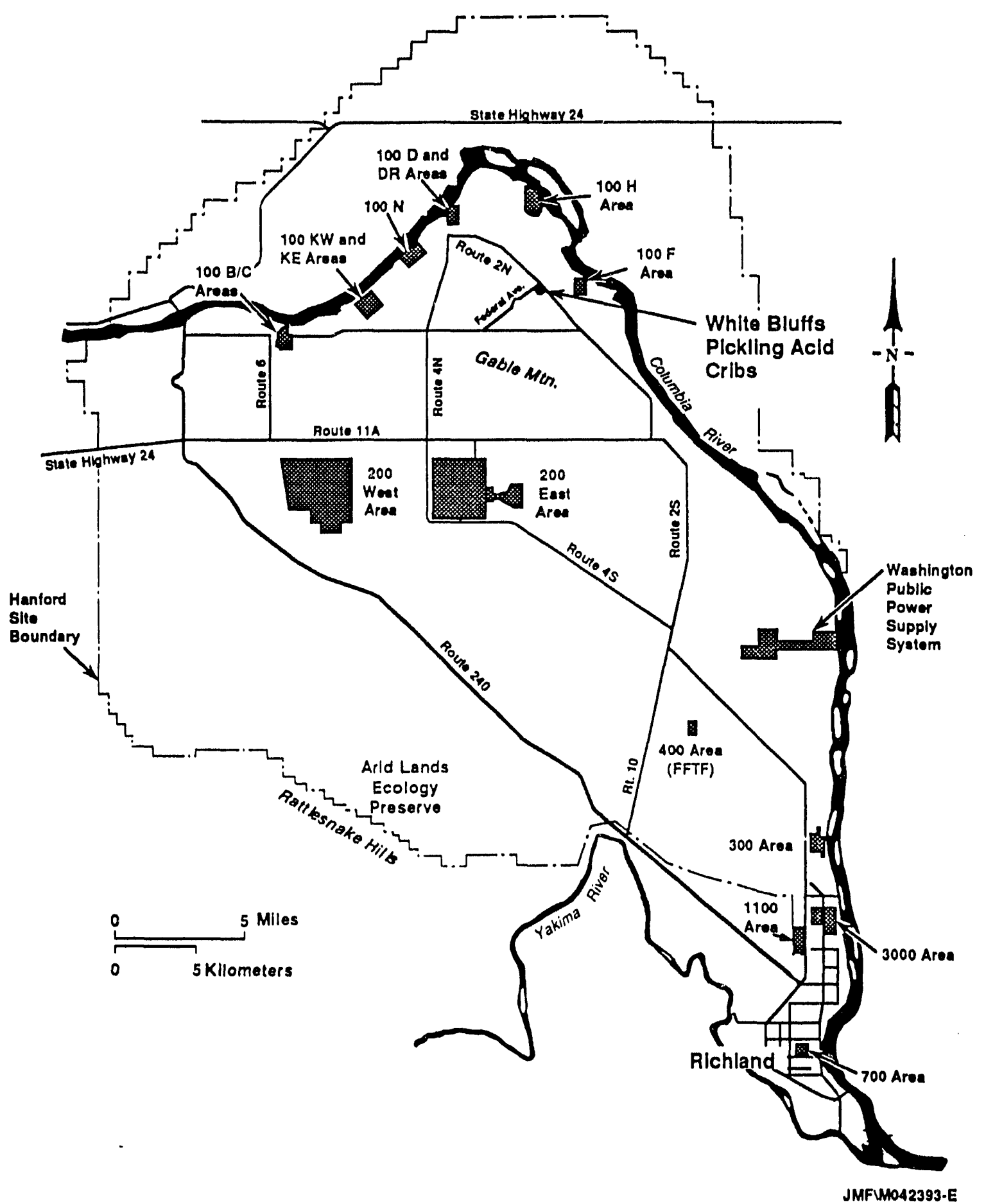


Figure 2. Location of the 100-IU-2 and 100-IU-5 Operable Units.

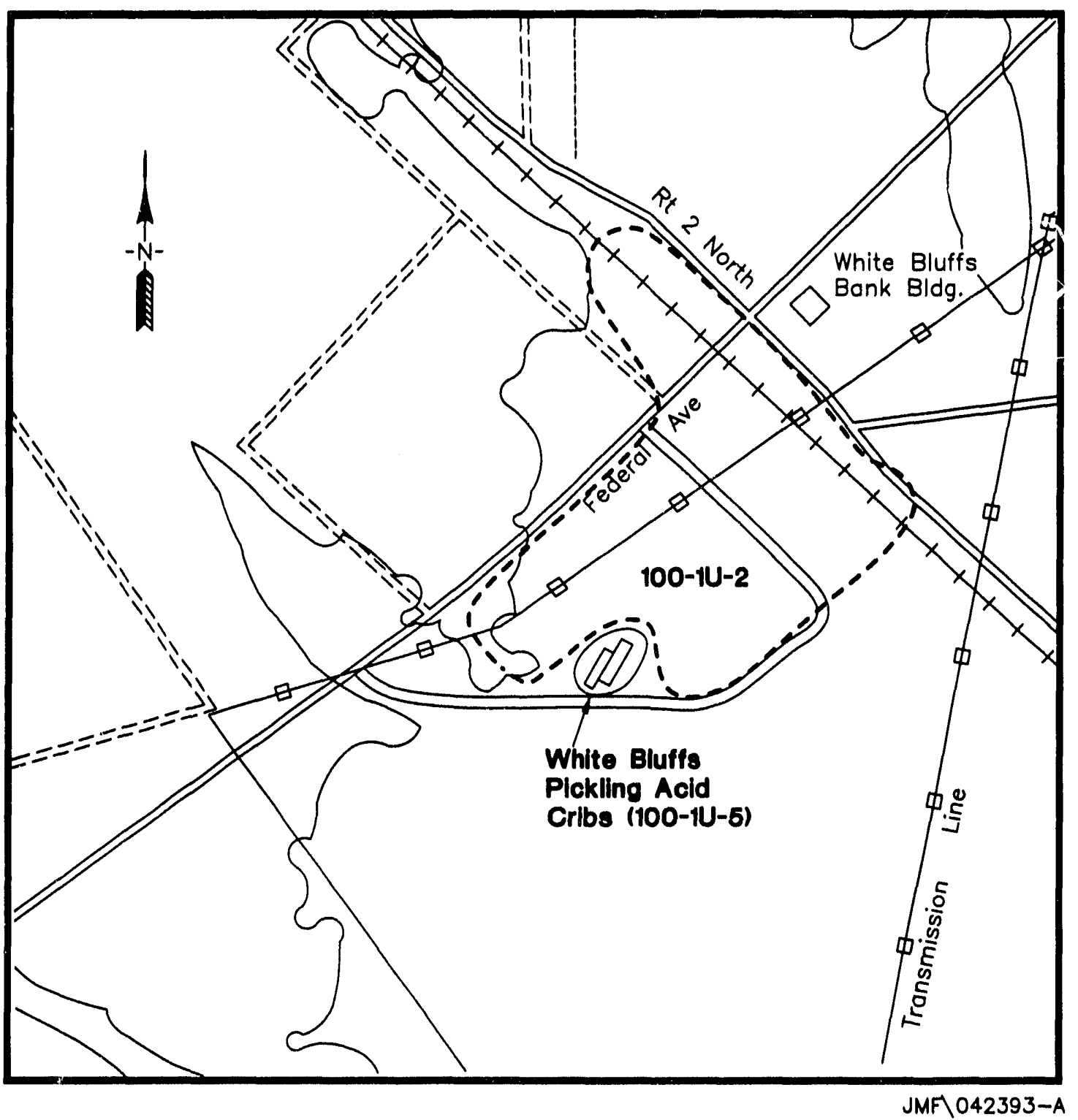

- 100-1U-5 Operable Unit Boundary

-. - 100-IU-2 Operable Unit Boundary

$=$ Dirt Road

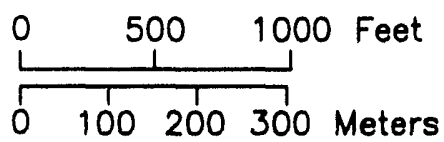


There are two pickling acid cribs at the site, located side by side, each approximately $200 \mathrm{ft}$ by $50 \mathrm{ft}$. Each crib contains three evenly spaced rows of vent pipes, spaced 7 to $9 \mathrm{ft}$ apart, which protrude from the cobbled surface of and run the length of each crib. A riser pipe, approximately 36-in. diameter, protruded from the northern end of the west crib (this pipe was removed during the investigation to obtain samples of soil beneath it). The cribs are fed by underground pipelines suspected to come from the northeast. These influent pipelines will be located and investigated with this ERA.

To the north and east of the cribs are areas that appear to have been disturbed. The debris in the area indicates the possible presence of a landfill and/or building demolition areas. These areas are included in and wi1l be investigated further as part of the 100-IU-2 operable unit. Investigation of the groundwater beneath 100-IU-5 wi11 be conducted during the 100-IU-2 investigation to effectively determine potential contamination sources.

\subsection{CHARACTERIZATION ACTIVITIES}

The objective of ERA characterization activities was to determine the nature and extent of any environmental hazards at the site in question. Site characterization activities at the cribs were conducted 1 ate in 1992 and consisted of radiological surveys, nonintrusive ground-penetrating radar (GPR) and electromagnetic induction (EMI) surveys, historical research, visual site surveys, and soil sampling. The results of these activities are presented in the following sections.

\subsection{RADIOLOGICAL SURVEYS}

It is known that the White Bluffs area was restricted from receiving radioactive materials during facility operations. Both surface surveys and subsurface soil samples were taken to confirm this observation. Neither of the radiological surveys detected any radioactivity distinguishable from background levels. So il sample data are presented in Appendix A.

\subsection{GEOPHYSICAL SURVEYS}

The GPR and EMI surveys conducted at the site in September 1992 (WHC 1992a) provided an initial look at the boundaries of the cribs and the subsurface piping layout (Figure 3 ). This information was used during the preparation of the sampling plan to identify sampling locations. A majority of the information identified in the preliminary investigation was confirmed during the subsurface soil sampling. Interestingly, the two influent pipes do not merge, as was suggested by the underground survey. This suggests different sources. The actual layout of the influent pipes has been sketched on Figure 3 . Figure 4 shows a section through each crib. 
DOE/RL-93-48, Rev. 0

Figure 3. GPR Report/Pipe Layout.

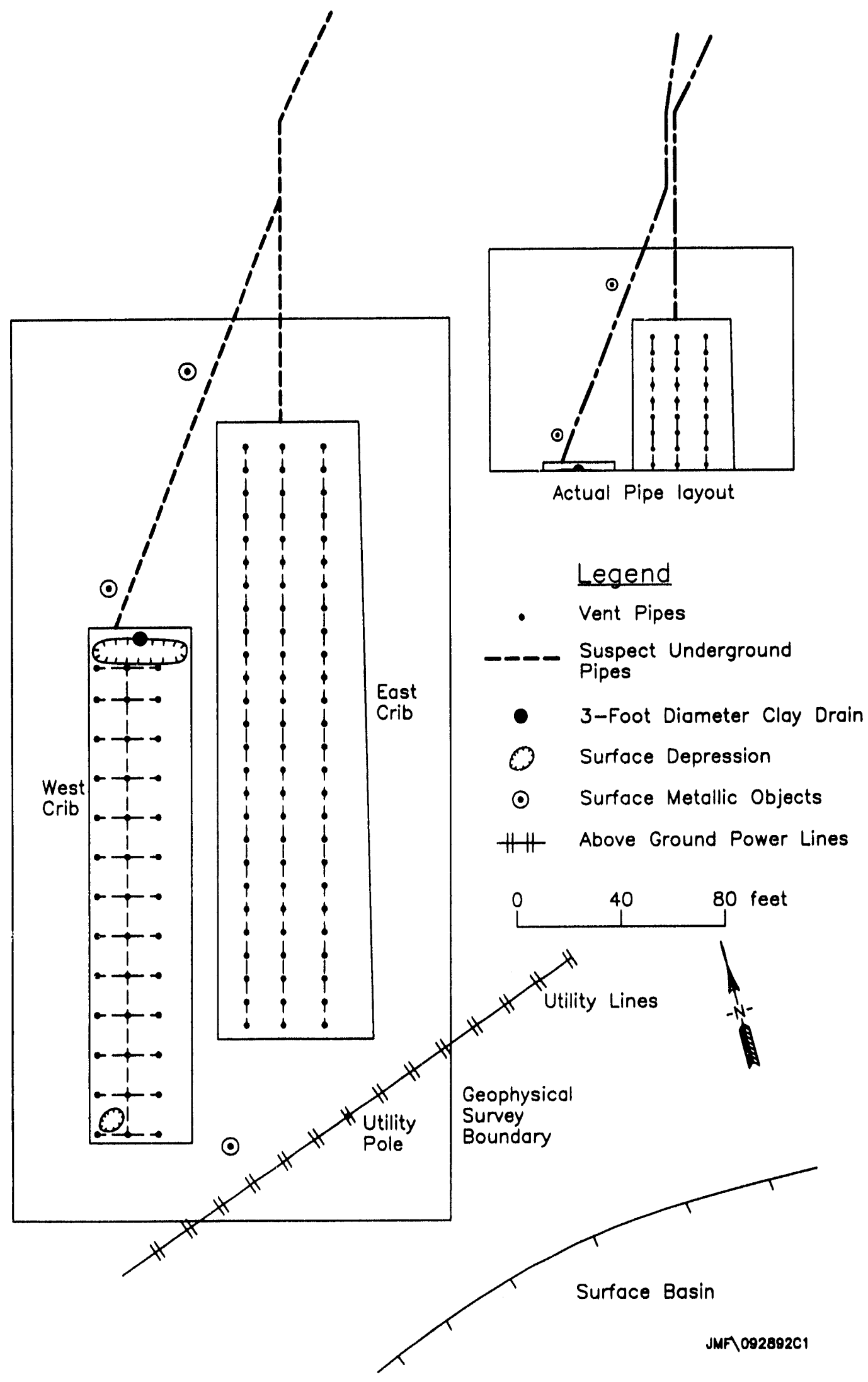


DOE/RL-93-48, Rev. 0

Figure 4. Plan and Sections Through Cribs.

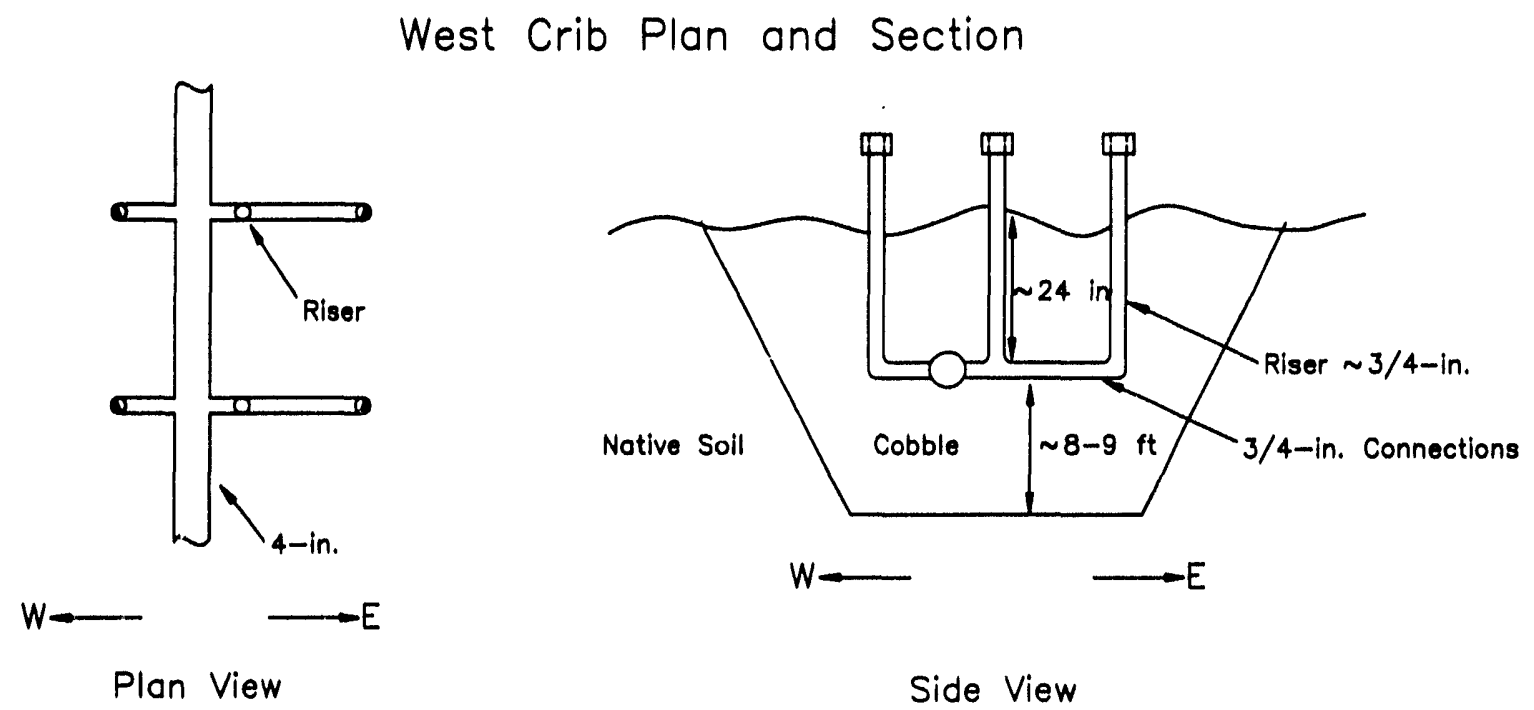

Plan East Crib Plan and Section
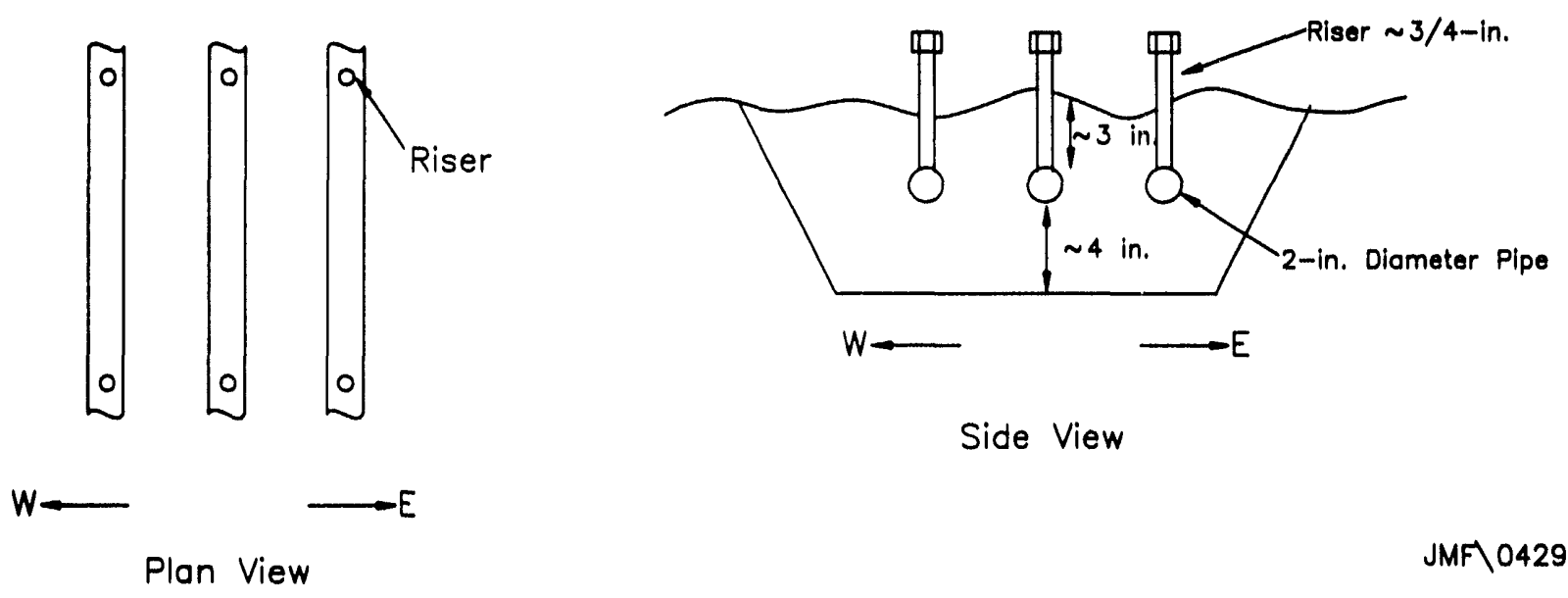

Side View

JMF $\ 042993-B$ 


\subsection{HISTORICAL RESEARCH}

Minimal historical data exist regarding the use of the White Bluffs Pickling Acid Cribs. Available information indicates only that the pickling process used "several thousand gallons of acid" (DOE-RL 1992); however, this volume is suspect since "several thousand gallons of acid" could refer to the acid etch solution, which is only $9-12 \%$ acid in an aqueous solution. While the information available was not specific regarding quantities, it was useful in narrowing the consiituents of concern for this ERA to acids and the etching byproducts.

\subsection{SAMPLING}

Soil samples were collected from December 1 through December 7, 1992. These samples were both field screened and analyzed at a qual ified analytical laboratory. A detailed sampling and analysis plan (WHC 1992b) was prepared for this activity. This document received regulatory approval prior to the initiation of sampling activities.

Both surface and intrusive soil samples were taken to determine the nature and extent of potential soil contamination. Surface sampling consisted of collecting soil samples to a depth of $1 \mathrm{ft}$ or less. Intrusive soil samples were obtained from test pits at depths to $16 \mathrm{ft}$ below the surface. Samples were taken directly beneath the soil cobble interface and $5 \mathrm{ft}$ below that level. The test pits were also used to verify the configuration of the piping system and provided a visual inspection of the crib construction. The excavated material (soil, cobbles) was returned to the cribs after samples were taken. Table 1 details the soil samples location and analyses, while Figure 5 maps the sampling locations. Sample results are presented and validated in the White Bluffs Pickling Acid Crib Expedited Response Action Data Validation Report (WHC 1993).

The sampling effort included investigating the crib's feeder pipes, which travel north out of both cribs, and a depression on the southeastern corner of the eastern crib ("D" samples on Figure 5), which may have been an overflow.

\subsection{DATA ASSESSMENT}

\subsection{CONTAMINANTS OF CONCERN}

Records indicate that the cribs were used as a disposal area for waste acids used to etch pipes. The sampling concentrated on looking for acids (nitric and hydrofluoric) and metals (chrome, zirconium) that might still be bound up in the soil. Over 35 years have lapsed since disposal to the facility ceased. Historical records did not indicate the disposal of other chemicals at the site; however, since it is known that the White Bluffs area was used as a receiving area for construction activities, it is also possible that oils and solvents may have been used during routine maintenance 
Table 1. Soil Sampling Locations and Analyses.

\begin{tabular}{|c|c|c|c|}
\hline $\begin{array}{l}\text { SAMPLE } \\
\text { SITE }\end{array}$ & $\begin{array}{l}\text { SAMPLE } \\
\text { IDENTIF IER } \\
(\text { HEIS \#) }\end{array}$ & LOCATION OF SAMPLE & ANALYSES \\
\hline A1 & B07PY8 & $\begin{array}{l}10 \mathrm{ft} \text { below surface, taken within } 1 \text { foot of } \\
\text { interface between soil and crib bottom. }\end{array}$ & fS \\
\hline A2 & B07P21 & $14 \mathrm{ft}$ below surface, directly beneath $\mathrm{A} 1$ & FS \\
\hline$A 3$ & B07PY9 & $9 \mathrm{ft}$ below surface & ss \\
\hline A4 & $\mathrm{B} 07 \mathrm{P} 23$ & $8 \mathrm{ft}$ below surface & ss \\
\hline B1 & B07P25 & $6.7 \mathrm{ft}$ below surface & SS \\
\hline B2 & B07PZ6 & $11-12 \mathrm{ft}$ below surface & FS \\
\hline B3 & B07P27 & $15-16 \mathrm{ft}$ below surface & FS \\
\hline 84 & B07P78 & $6.7 \mathrm{ft}$ below surface & SS \\
\hline B5 & B07PZ9 & $5-6 \mathrm{ft}$ below surface & ss \\
\hline B6 & 807000 & $10-11 \mathrm{ft}$ below surface & SS \\
\hline B7 & 807001 & $5.6 \mathrm{ft}$ below surface & FS \\
\hline B8 & B07003 & $10-11 \mathrm{ft}$ below surface & FS \\
\hline B9 & B07004 & $5.6 \mathrm{ft}$ below surface & ss \\
\hline B10 & B07005 & 10-11 ow surface & ss \\
\hline$c 1$ & B07006 & $3-4 \mathrm{ft} \quad \checkmark$ surface & ss \\
\hline $\mathrm{C2}$ & B07009 & $4.5 \mathrm{ft} \quad$ W surface & SS \\
\hline $\mathrm{c} 3$ & B07007 & $3-4 \mathrm{ft}, \quad$ w surface & ss \\
\hline $\mathrm{C4}$ & 807008 & $3.4 \mathrm{ft} \quad$ w surface & ss \\
\hline D1 & 807010 & 6.12 ir low surface & SS \\
\hline D2 & B07011 & $6-12$ il below surface & ss \\
\hline D3 & B07012 & 6.12 ir below surface & FS \\
\hline E1 & B07PZ2 & $7 \mathrm{ft}$ below surface & FS \\
\hline E2 & B07PZ4 & $12 \mathrm{ft}$ below surface & FS \\
\hline NA & B07002 & Duplicate of sample B07001 & FS \\
\hline NA & $B 07013$ & Split of sample B07012 & FS \\
\hline NA & $\begin{array}{l}\text { B07014, B07Q15, } \\
\text { B07016 }\end{array}$ & $\begin{array}{l}\text { Background samples, taken in undisturbed soil } \\
\text { west of the cribs ( } 6-12 \text { inches below surface) }\end{array}$ & ss \\
\hline NA & B07PZO & Equipment $\mathrm{Bl}$ ank & ss \\
\hline
\end{tabular}

FS = Indicates sample was analyzed for the full suite of analyses, which includes IAL Metals, 6010 FOR ZR, Anions (EPA 300.0), Nitrate/nitrite (EPA 353.2), Ammonia, pH, Calcium Carbonate (Hardness, EPA 130.2), Semi-VOA (CLP), VOA (CLP), Gamma Spec, TPH (Diesel Range), TPH (Heavier than Diesel Range)

SS = The short list samples were analyzed for expected contaminants. These are all categories in the FS list that have been underlined.

$N A=$ Not Applicable, sample site not numbered. 
DOE/RL-93-48, Rev. 0

Figure 5. Soil Sampling Locations.

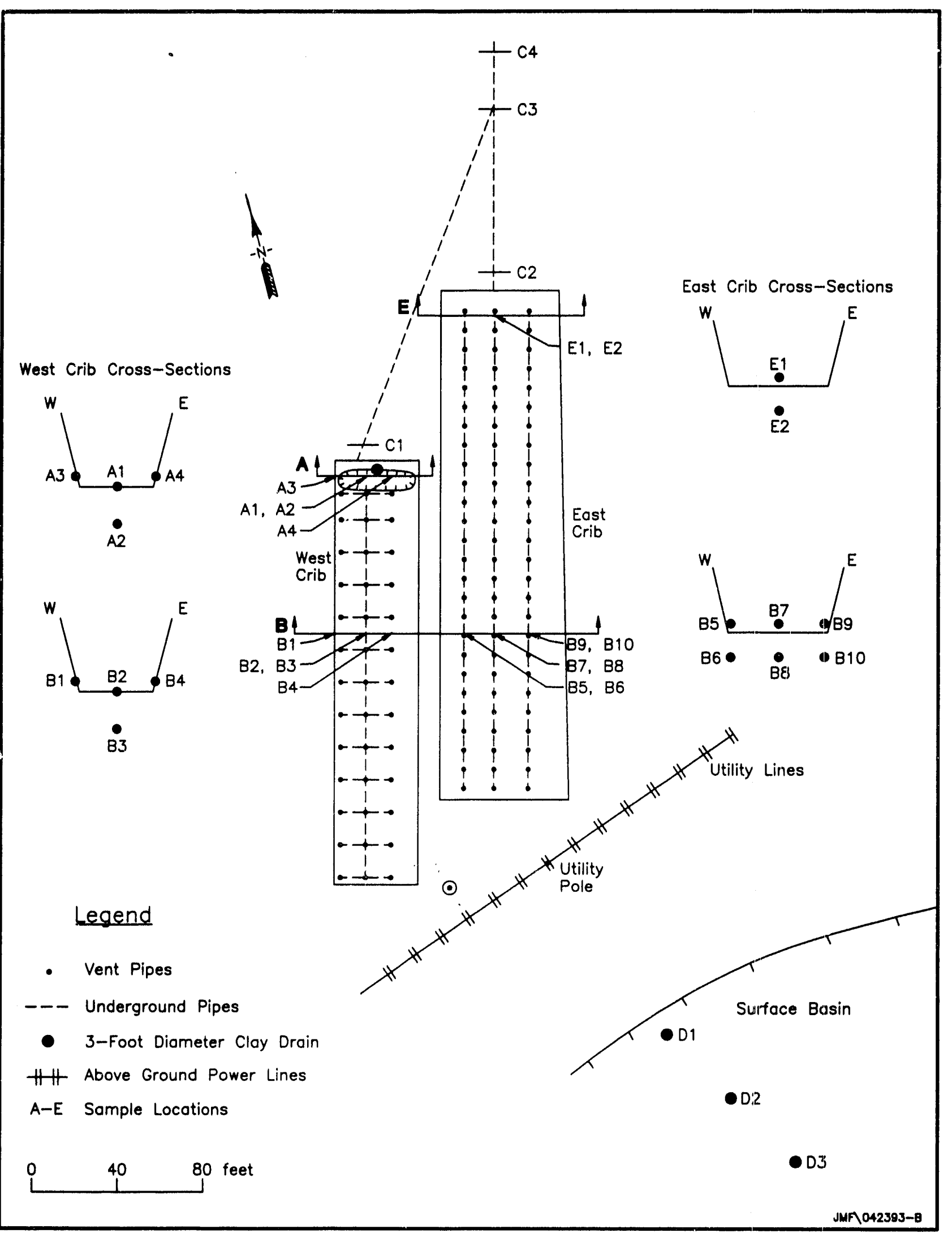


activities and sent through a drain to the cribs. Some samples were analyzed for other chemicals (organics, radionuclides) that could indicate other waste products that might have been discarded.

\subsection{DATA VALIDATION}

A11 samples sent to offsite laboratories were analyzed per EPA Level IV quality (radiological samples, Level $V$ ), and the analysis results have been sent to an offsite contractor for data validation (WHC 1993). Validation reports have qualified the data as indicated in Tables 2 and 3 presented in Section 4.3.

\section{4.: DATA TABLES}

Tables 2 and 3 present the condensed results of soil sampling analysis. The tables have been separated into anions and metals, which were the primary contaminants of concern. Both sets of data have been condensed to include onty metals and anions, which would be indicators of acid etch solution disposal. A complete set of all sample analysis results is provided in Appendix A. The definition of qualifiers is presented below.

$U$ Indicates the compound or analyte was analyzed for and not detected. The value reported is the sample quantitation limit corrected for sample dilution and moisture content by the laboratory.

UJ Indicates the compound or analyte was analyzed for and not detected. Because of quality control (QC) deficiencies identified during data validation, the value reported may not accurately reflect the sample quantitation limit.

$\mathrm{J}$ Indicates the compound or analyte was analyzed for and detected. The associated value is estimated, but the data are usable for decision-making processes.

$R$ Indicates the compound or analyte was analyzed for and because of an identified $Q C$ deficiency the data are not usable.

JN Indicates presumptive evidence of a compound at an estimated value.

VJN Indicates the compound or analyte was originally identified from presumptive evidence. Because of QC deficiencies identified during data validation, the value reported may not accurately reflect the sample quantitation limit. 
DOE/RL-93-48, Rev. 0

Table 2. Metals (Reported in $\mathrm{mg} / \mathrm{kg}$ ). (Sheet 1 of 2)

\begin{tabular}{|c|c|c|c|c|c|c|c|c|c|c|c|c|c|c|c|c|c|c|c|c|c|c|c|c|}
\hline$\stackrel{\infty}{N}$ & $\begin{array}{l}\Rightarrow \\
\Rightarrow\end{array}$ & $\begin{array}{l}7 \\
n \\
=\end{array}$ & : & 㓩 & $\hat{\beth}$ & \begin{tabular}{l}
7 \\
\multirow{2}{*}{}
\end{tabular} & $\begin{array}{l}7 \\
0 \\
0 \\
0\end{array}$ & $\stackrel{0}{\stackrel{0}{\circ}}$ & 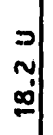 & $\begin{array}{l}\vec{a} \\
\hat{a} \\
=\end{array}$ & $\begin{array}{l}\overrightarrow{ } \\
\overrightarrow{0} \\
0\end{array}$ & $\stackrel{m}{=}$ & $\begin{array}{l}\vec{D} \\
0 \\
0 \\
0\end{array}$ & 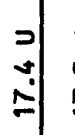 & $\begin{array}{l}\vec{n} \\
\tilde{n} \\
\hat{n}\end{array}$ & $\begin{array}{l}\vec{a} \\
a \\
0 \\
0\end{array}$ & $\begin{array}{l}\overrightarrow{7} \\
\text { - } \\
-0\end{array}$ & $\begin{array}{l}3 \\
0 \\
0 \\
0\end{array}$ & $\check{\infty}$ & $\begin{array}{l}د \\
\stackrel{m}{2} \\
\end{array}$ & 궉 & $\begin{array}{l}0 \\
\dot{\omega}\end{array}$ & $\begin{array}{l}\vec{a} \\
\hat{a}\end{array}$ & $\hat{\alpha}$ \\
\hline $\mathbb{N}$ & $\stackrel{\infty}{\rightarrow-1}$ & जे. & î̀ & : & $\frac{1}{0}$ & m. & $m$ & 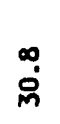 & जे & m. & 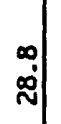 & 竞 & $\begin{array}{l}a \\
0 \\
0\end{array}$ & 品 & 品 & $\begin{array}{l}0 \\
\stackrel{0}{*}\end{array}$ & 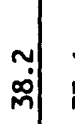 & m̊ & $\hat{m}$ & 官 & $\begin{array}{l}0 \\
0 \\
0\end{array}$ & $\begin{array}{l}0 \\
\text { ¿்̇ } \\
\end{array}$ & $\begin{array}{l}0 \\
0 \\
0 \\
0\end{array}$ & $\begin{array}{l}\hat{y} \\
\tilde{w}\end{array}$ \\
\hline $\mathbf{z}$ & $\begin{array}{l}\infty \\
0\end{array}$ & $\begin{array}{l}m \\
\infty\end{array}$ & $a$ & $\frac{\infty}{2}$ & $\stackrel{\infty}{\sim}$ & $\stackrel{\infty}{\infty}$ & ?: & $\stackrel{\circ}{a}$ & $\begin{array}{l}m \\
\vdots \\
\vdots\end{array}$ & \begin{tabular}{l}
$\infty$ \\
\hdashline \\
\end{tabular} & $\begin{array}{l}\infty \\
0 \\
\infty\end{array}$ & - & $\stackrel{m}{m}$ & $\begin{array}{l}\infty \\
\infty \\
\infty\end{array}$ & $\begin{array}{l}\infty \\
\stackrel{0}{0} \\
0\end{array}$ & 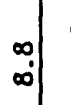 & @: & aे & $\dot{\Phi}$ & $\stackrel{\infty}{a}$ & $=$ & : & 齐 & $\stackrel{\infty}{a} a^{\circ}$ \\
\hline$\frac{7}{2}$ & $\stackrel{\infty}{\sim}$ & $\vec{\Xi}$ & $\underline{F}$ & 9 & $\bar{n}$ & 气̊? & $\stackrel{-m}{\sim}$ & $\stackrel{\infty}{\varrho}$ & సี & $\begin{array}{l}7 \\
y\end{array}$ & $\underline{\underline{E}}$ & $\vec{a}$ & 峉 & $\stackrel{-a}{-}$ & ఏ & $\stackrel{2}{-2}$ & $\cong$ & $\stackrel{\infty}{\sim}$ & $\Phi$ & 워 & $\stackrel{2}{m}$ & $\sqrt{\tilde{N}}$ & $\stackrel{2}{-2}$ & 요 \\
\hline
\end{tabular}

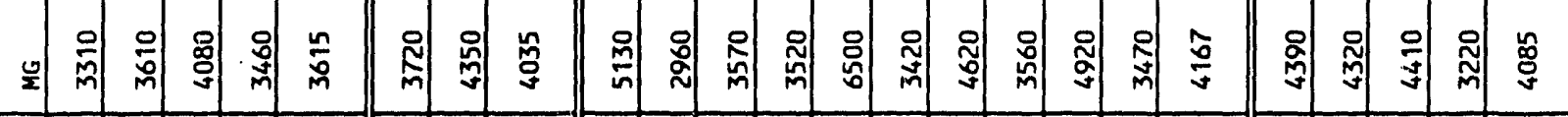

a

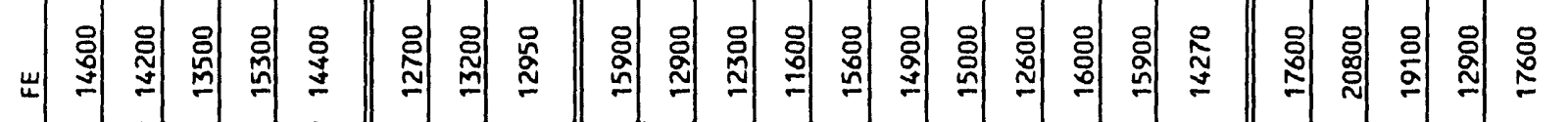

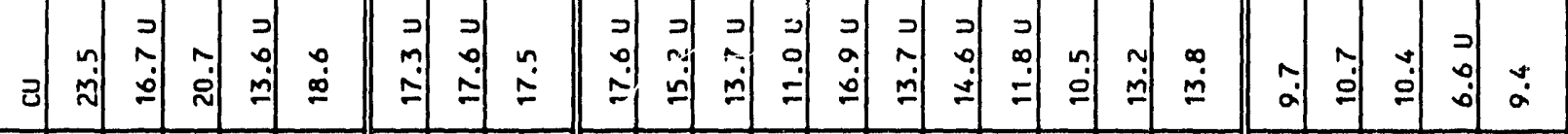

$\therefore$ á.

×

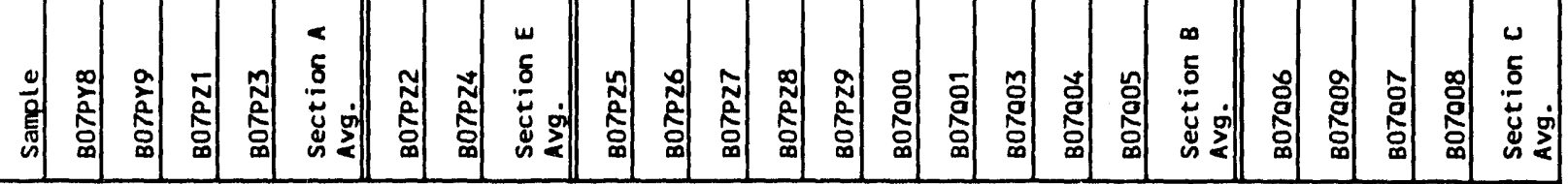


DOE/RL-93-48, Rev. 0

Table 2. Metals (Reported in $\mathrm{mg} / \mathrm{kg}$ ). (Sheet 2 of 2)

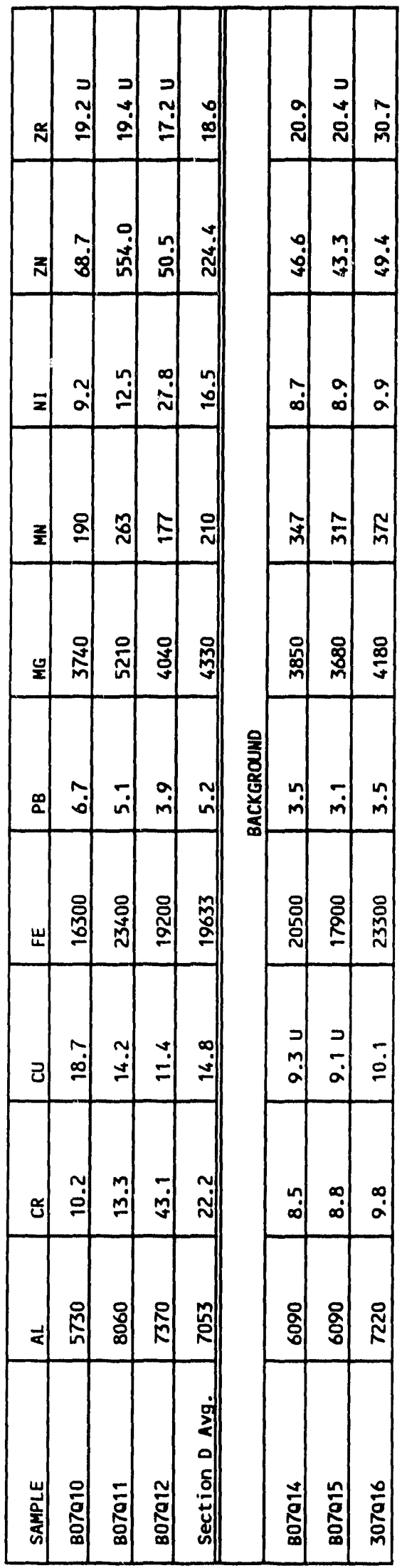


Table 3. Anions (Reported in $\mathrm{mg} / \mathrm{kg}$ ).

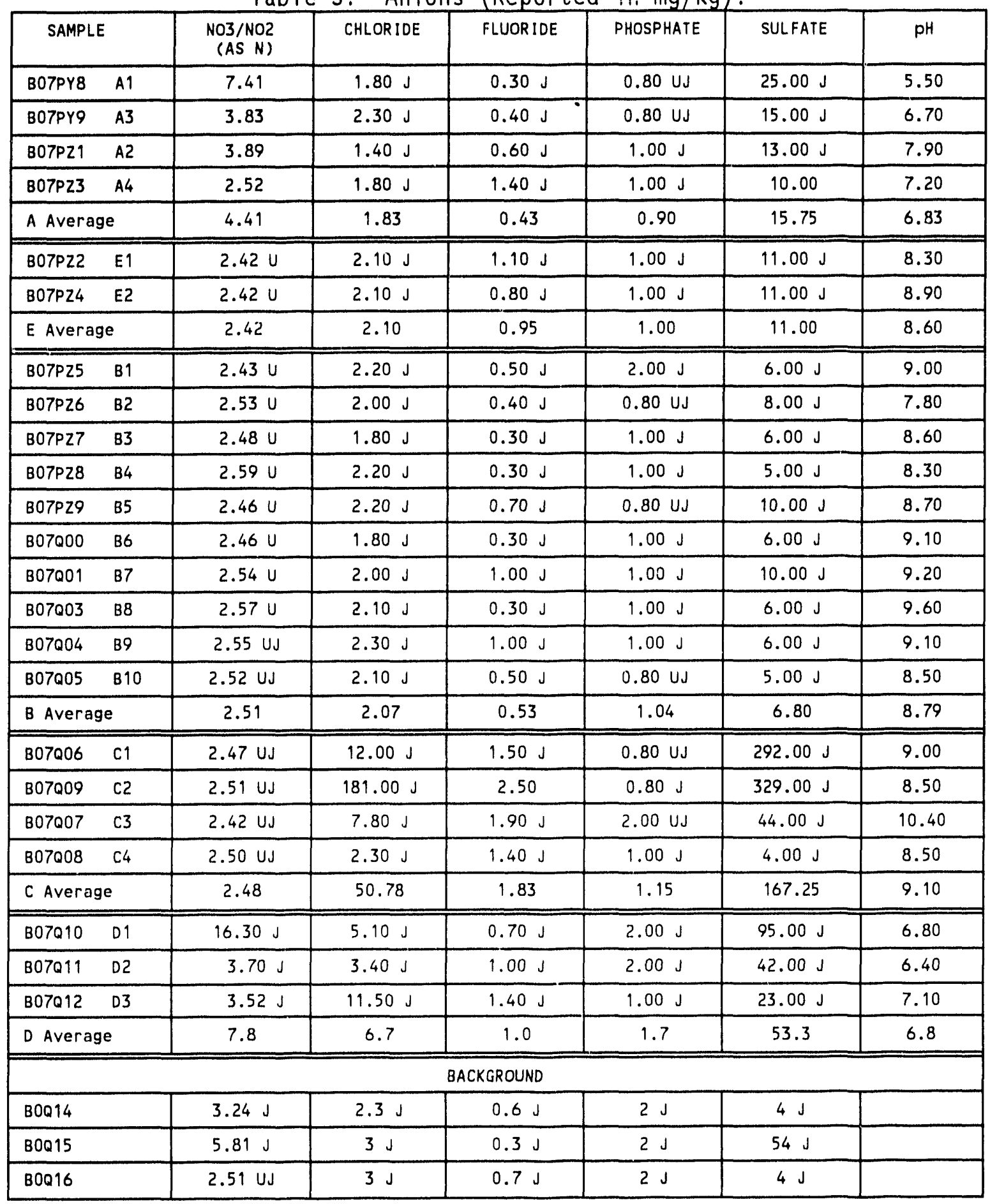




\subsection{DATA SUMMARY}

A review of the analytical data indicated none of the contaminants present a risk to human helath or the environment. Most chemical concentrations are well within the range of background concentrations obtained from samples taken in undisturbed soil by the White Bluffs Cribs site. Data were also compared with the Hanford Site-wide background 95/95 reference threshold values (DOE-RL 1993a).

The chemicals with average concentrations above background are chromium, copper, and zinc (Table 4). For these constituents, risk-based goals were calculated using the most conservative assumptions (residential scenario) from the Hanford Site Baseline Risk Assessment Methodology (DOE-RL 1993b). The goals are protective of human health at a $1 \times 10^{-6}$ incremental cancer risk for carcinogens or a hazards of 1.0 for systemic toxicity. The maximum detected concenetrations of chromium and zinc were well below these risk-based goals. Sufficient toxicological information is not available to calculate a value for copper.

Table 4. Risk Evaluation for Chemicals with Concentrations Above Background.

\begin{tabular}{|c|c|c|c|}
\hline $\begin{array}{c}\text { Chemical of } \\
\text { concern } \\
\text { (Ave. detected } \\
\text { background) }\end{array}$ & $\begin{array}{c}\text { Background } \\
\text { range (mg/kg) } \\
{\left[\mathrm{DOE} / \mathrm{RL}-92-24^{\mathrm{a}}\right]}\end{array}$ & $\begin{array}{c}\text { Detected range } \\
\text { (Average-mg/kg) }\end{array}$ & $\begin{array}{c}\text { Lowest risk- } \\
\text { based goal for } \\
\text { soi1 (mg/kg) }\end{array}$ \\
\hline Chromium & $\begin{array}{c}8.5-9.8 \\
{[28]}\end{array}$ & $\begin{array}{c}6.5-43.1 \\
(10.52)\end{array}$ & 8000 \\
\hline Copper & $\begin{array}{c}9.3-10.1 \\
{[30]}\end{array}$ & $\begin{array}{c}6.6-23.5 \\
(13.37)\end{array}$ & $\begin{array}{c}\text { Data not } \\
\text { available }\end{array}$ \\
\hline Zinc & $\begin{array}{c}23.3-46.6 \\
{[79]}\end{array}$ & $\begin{array}{c}28-1070^{\mathrm{c}} \\
(137.7)\end{array}$ & 2400 \\
\hline
\end{tabular}

${ }^{a} D 0 E-R L(1993 a)$.

${ }^{b}$ Copper toxicity values are not in the EPA's integrated Risk Information System, which was used to develop risk-based standards.

'The highest values of zinc were found directly beside the galvanized pipe. The value was most likely elevated due to the presence of metal pipe scrapings in the sample, since the pipe was hit while excavating to expose it, or from pipe corrosion. The lower set of values corresponds to range and average if the highest value is thrown out. 


\subsection{APPLICABLE OR RELEVANT AND APPROPRIATE REQUIREMENTS}

Section 7.5 of the Action P1an in the Hanford Federal Facility Agreement and Consent Order (Ecology et a1. 1989) contains the basic description of applicable or relevant and appropriate requirements (ARAR).

There are no applicable federal cleanup standards or chemical-specific ARARs for compounds in soil (hazardous or radioactive) except the EPA standards for lead and radium. Washington State Regulations (WAC 173-340) provide soil cleanup standards; however, because the sampling data do not indicate any contamination of the background levels, the cribs are not a threat to human health and/or the environment.

\subsection{CONCLUSIONS AND RECOMMENDATIONS}

The chemical concentrations detected at the White Bluffs Pickling Acid cribs site do not indicate that the cribs pose any threat to human health or the environment, since the chemicals detected are well within background soil concentration ranges. Therefore, the site no longer exists as a potential source of contamination to the groundwater. Historical releases to the cribs may have released some chemical inventory to the grouridwater; however, because the unit is bordered on three sides by 100-IU-2, groundwater sampling in the vicinity of the pickling acid cribs will not clearly determine if the cribs were a source of contamination until the waste units surrounding them are investigated. Groundwater will be investigated with the 100-1U-2 operable unit.

No action to remove contamination is required for the completion of the White Bluffs Pickling Acid Cribs ERA. It is recommended that a No Further Action Interim Record of Decision be issued to the DOE for the vadose zone in the 100-IU-5 operable unit. It is further recommended that the physical hazards associated with the cribs be removed froll the site as a landlord cleanup action.

\subsection{REFERENCES}

Comprehensive Environmental Response, Compensation, and Liability Act of 1980, as amended, Public Law 96-510, 94 Stat. 2767, 26 USC 1 et seq.

DOE-RL, 1992, Hanford Site Waste Management Units Report, DOE/RL-88-30, U.S. Department of Energy, Richland Field Office, Richland, Washington.

DOE-RL, 1993a, Hanford Site Background: Part 1, Soil Background for Nonradioactive Analytes, DOE/RL-92-24, Rev. 1, U.S. Department of Energy, Richland Operations Office, Richland, Washington.

DOE-RL, 1993b, Hanford Site Baseline Risk Assessment Methodology, DOE/RL-91-45, Rev. 2, U.S. Department of Energy, Richland Field Office, Richland, Washington. 
Ecology, EPA, and DOE, 1989, Hanford Federal Facility Agreement and Consent Order, et seq., Washington State Department of Ecology, U.S.

Environmental Protection Agency, and U.S. Department of Energy, 01ympia, Washington.

EPA, 1990, National $0 i 7$ and Hazardous Substances Pollution Contingency Plan, Title 40, Code of Federal Regulations, Part 300, U.S. Environmental Protection Agency, Washington, D.C.

Resource Conservation and Recovery Act of 1976, Public Law 94-580, 90 Stat. 2795, 42 USC 6901 et seq.

WAC 173-340, Model Toxics Control Act, Washington State Department of Ecology, 01 ympia, Washington.

WHC, 1992a, Geophysical Survey of the White Bluffs Cribs Site, WHC-SD-EN-ER-002, Rev. 0, Westinghouse Hanford Company, Richland, Washington.

WHC, 1992b, White Bluffs Pickling Acid Crib Expedited Response Action Project Plan, WHC-SD-EN-AF-113, Rev. 0, Westinghouse Hanford Company, Richland, Washington.

WHC, 1993, White Bluffs Pickling Acid Crib Expedited Response Action Data Validation Report, WHC-.SD-EN-TI-159, Rev. 0, Westinghouse Hanford Company, Richland, Washington. 
DOE/RL-93-48, Rev. 0

\section{APPENDIX A}

ANALYTICAL DATA 
DOE/RL-93-48, Rev. 0 
DOE/RL-93-48, Rev. 0

\section{APPENDIX A}

\section{ANALYTICAL DATA}

The following are definitions of data qualifiers used in the tables in this appendix.

$U$ Indicates the compound or analyte was analyzed for and not detected. The value reported is the sample quantitation limit corrected for sample dilution and molsture content by the laboratory.

UJ Indicates the compound or analyte was analyzed for and not detected. Because of quality control (OC) deficiencies identified during data validation, the value reported may not accurately reflect the sample quantitation limit.

$J$ Indicates the compound or analyte was analyzed for and detected. The associated value is estimated, but the data are usable for decision-making processes.

$R$ Indicates the compound or analyte was analyzed for and because of an identified $Q C$ deficiency the data are not usable.

JN Indicates presumptive evidence of a compound at an estimated value.

VJN Indicates the compound or analyte was originally identified from presumptive evidence. Because of QC deficiencies identified during data validation, the value reported may not accurately reflect the sample quantitation limit. 
DOE/RL-93-48, Rev. 0 
Table A-1. Metals Analysis and Qualifier Summary. (sheet 1 of 3 )

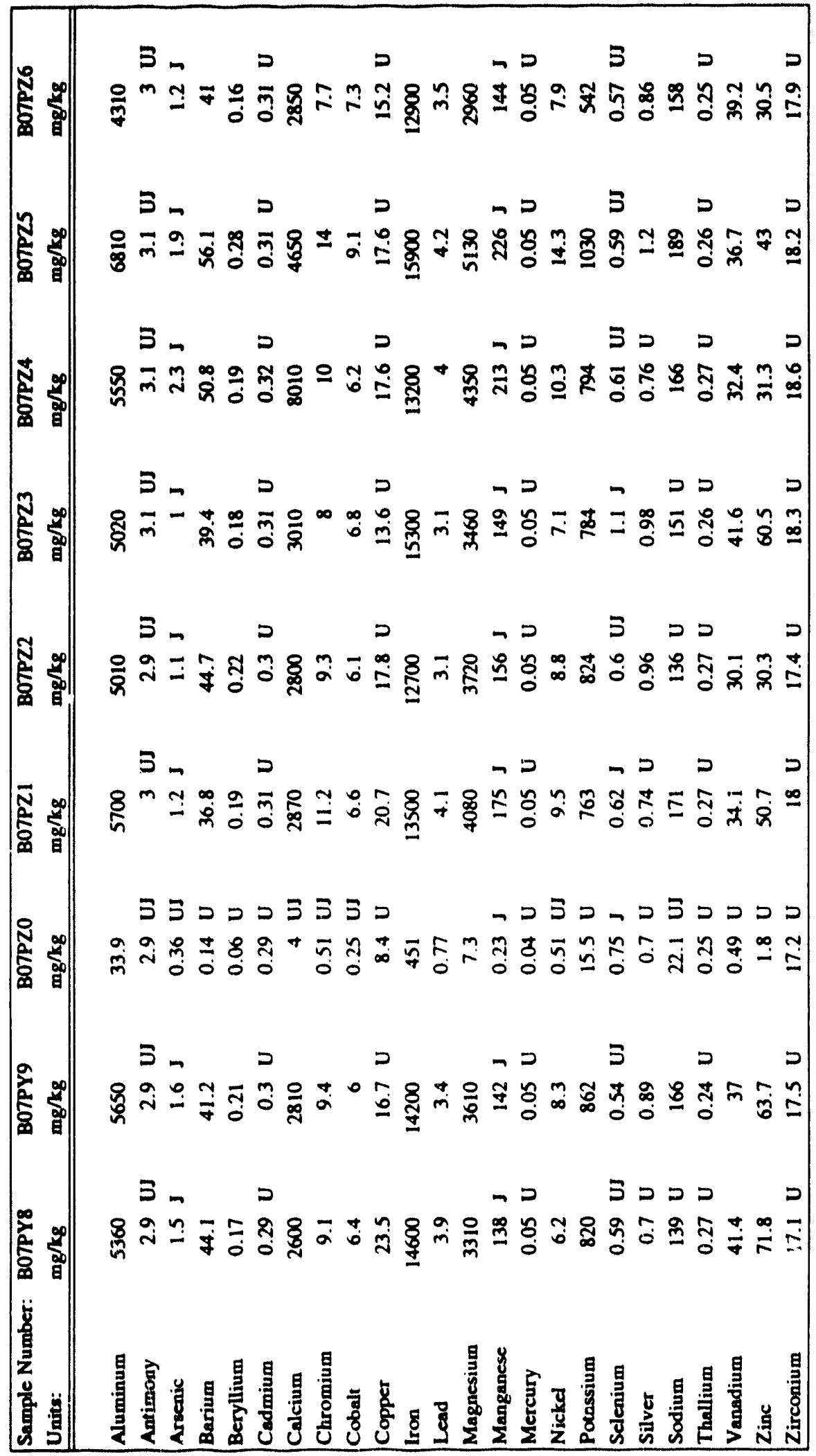


Table A-1. Metals Analysis and Qualifier Summary. (sheet 2 of 3)

\begin{tabular}{|c|c|}
\hline 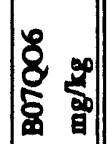 & 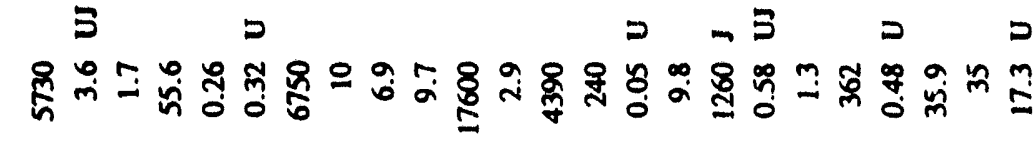 \\
\hline $5^{\infty}$ & 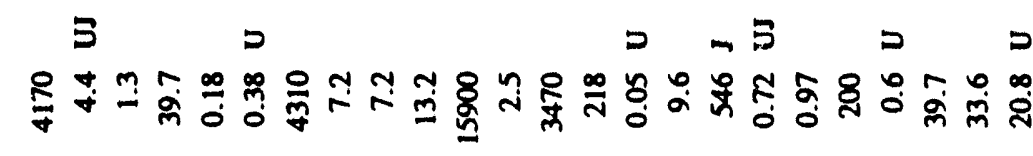 \\
\hline 50 & 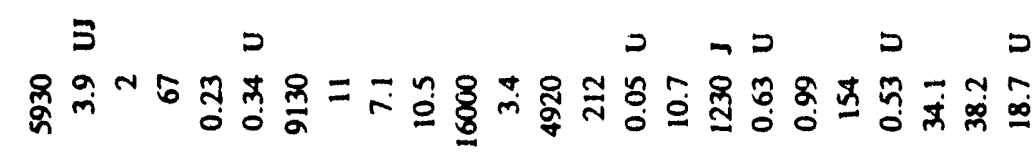 \\
\hline 92 & 羿 \\
\hline 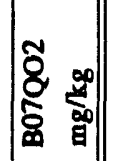 & 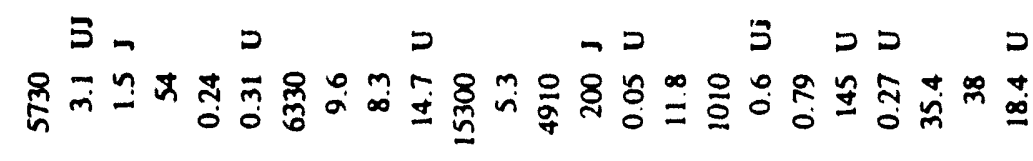 \\
\hline 8 & 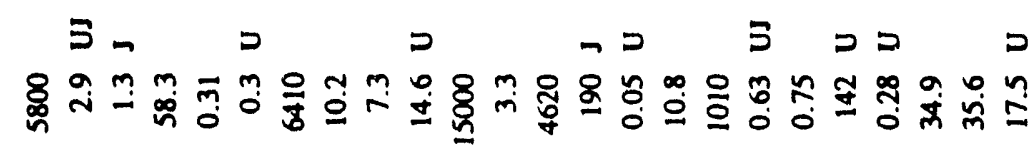 \\
\hline 5 & 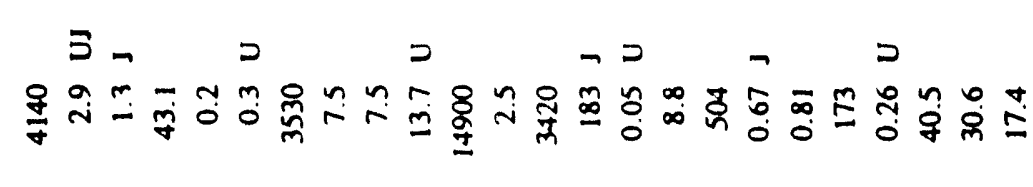 \\
\hline & 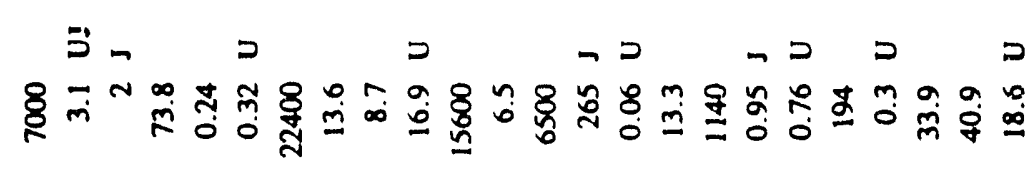 \\
\hline & 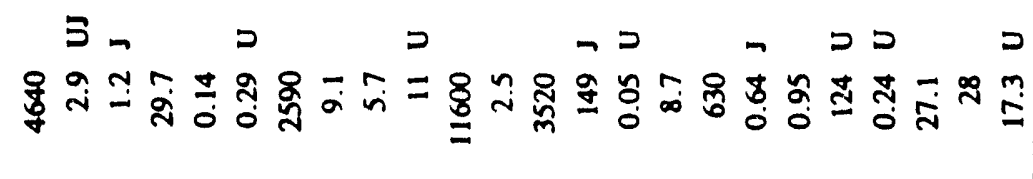 \\
\hline & 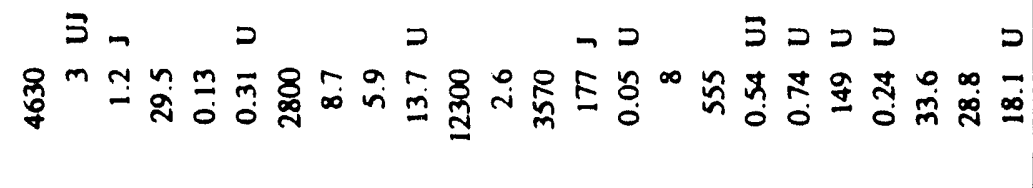 \\
\hline & 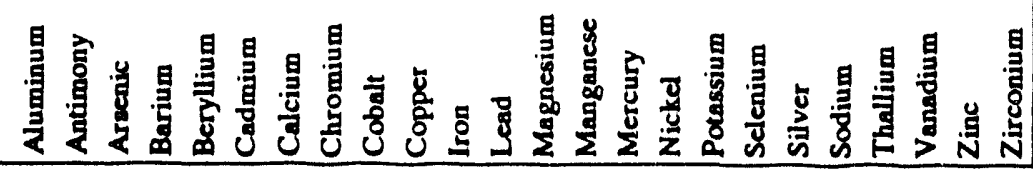 \\
\hline
\end{tabular}


Table A-1. Metals Analysis and Qualifier Summary. (sheet 3 of 3 )




DOE/RL-93-48, Rev. 0

A-8 
DOE/RL-93-48, Rev. 0

Table A-2. Anions and Nitrate/Nitrite Analysis and Qual ifier Summary. (sheet 1 of 3 )



$A-9$ 
DOE/RL-93-48, Rev. 0

Table A-2. Anions and Nitrate/Nitrite Analysis and Qualifier Summary. (sheet 2 of 3 )

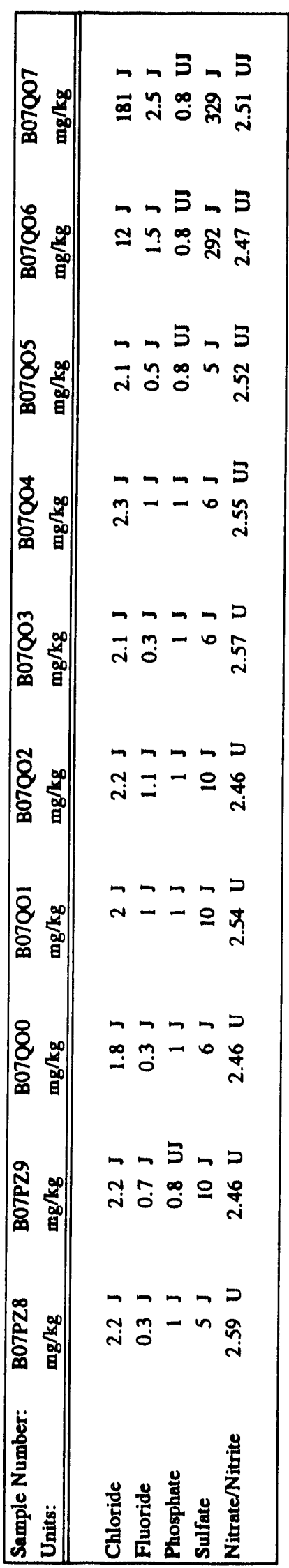


DOE/RL-93-48, Rev. 0

Table A-2. Anions and Nitrate/Nitrite Analysis and Qualifier Summary. (sheet 3 of 3 )

\begin{tabular}{|c|c|}
\hline 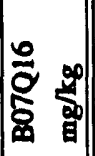 & $\ddot{m} \tilde{\sigma} \sim \overrightarrow{\bar{n}}$ \\
\hline 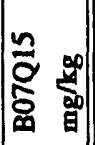 & 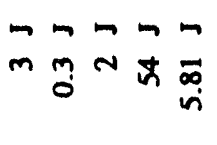 \\
\hline 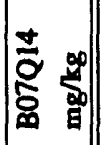 & $\vec{m} \ddot{O} \tilde{i}+\vec{m}$ \\
\hline 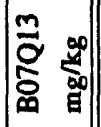 & 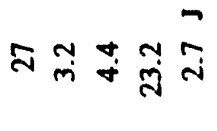 \\
\hline 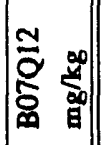 & 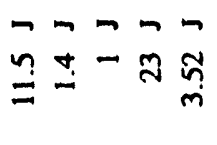 \\
\hline 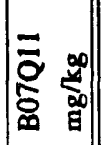 & $\overrightarrow{\dot{m}} \vec{\sim} \vec{\sim} \vec{q}$ \\
\hline 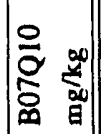 & $\overrightarrow{\tilde{n}} \overline{0} \approx \tilde{m}$ \\
\hline 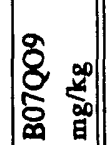 & 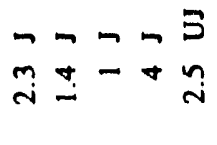 \\
\hline 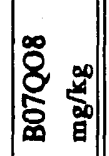 & 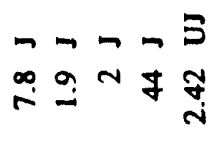 \\
\hline 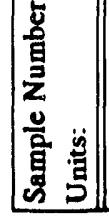 & 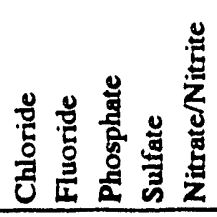 \\
\hline
\end{tabular}


DOE/RL-93-48, Rev. 0 
DOE/RL-93-48, Rev, 0

Table A-3. Radiochemical Analysis and Qualifier Summary.

\begin{tabular}{|c|c|c|c|c|c|c|c|c|}
\hline \multirow[b]{2}{*}{$\begin{array}{l}\text { Customer } \\
\text { I.D. No. }\end{array}$} & \multicolumn{2}{|c|}{ Cobalt 60} & \multicolumn{2}{|c|}{ Cesium 137} & \multicolumn{2}{|c|}{ Radium 226} & \multicolumn{2}{|c|}{ Thorium 228} \\
\hline & $\begin{array}{l}\text { Reported } \\
\text { Results } \\
\text { in } \mathrm{pCi} / \mathrm{L}\end{array}$ & Qualifier & $\begin{array}{l}\text { Reported } \\
\text { Results } \\
\text { in } \mathrm{pCi} / \mathrm{L}\end{array}$ & Qualifier & $\begin{array}{l}\text { Reported } \\
\text { Results } \\
\text { in } \mathrm{pCi} / \mathrm{L}\end{array}$ & Qualifier & $\begin{array}{l}\text { Reported } \\
\text { Results } \\
\text { in } \mathrm{pCi} / \mathrm{L}\end{array}$ & Qualifier \\
\hline \multicolumn{9}{|c|}{ TMA N2-12-018-7133 } \\
\hline B07PY8 & $<0.05$ & $\bar{U}$ & $<0.04$ & $\bar{U}$ & 0.47 & & 0.71 & \\
\hline B07PZ1 & $<0.10$ & U & $<0.10$ & U & 0.45 & & 0.69 & \\
\hline *B07PZ2 & $<0.03$ & U & $<0.03$ & $\mathrm{U}$ & 0.49 & & 0.73 & \\
\hline B07PZ4 & $<0.04$ & $U$ & $<0.03$ & U & 0.51 & & 0.99 & \\
\hline B07PZ6 & $<0.05$ & $U$ & $<0.04$ & $U$ & 0.48 & & 0.83 & \\
\hline B07PZ7 & $<0.05$ & U & $<0.04$ & $U$ & 0.42 & & 0.63 & \\
\hline B07Q01 & $<0.04$ & U & $<0.04$ & U & 0.57 & & 0.93 & \\
\hline *B07Q02 & $<0.06$ & U & $<0.05$ & U & 0.56 & & 0.81 & \\
\hline B07Q03 & $<0.05$ & U & $<0.04$ & U & 0.50 & & 0.70 & \\
\hline $\mathrm{B} 07 \mathrm{Q} 12$ & $<0.05$ & $\mathrm{U}$ & $<0.05$ & $\mathrm{U}$ & 0.56 & & 1.00 & \\
\hline \multicolumn{9}{|c|}{ Weston 9212L005 } \\
\hline B07Q13 & $<0.00591$ & $\overline{U J}$ & 0.0156 & $\mathrm{~J}$ & 0.497 & $\mathrm{~J}$ & N/A & \\
\hline
\end{tabular}

* - Fully validated sample

JOBSI297856IPIC6-1.wkI 
DOE/RL-93-48, Rev. 0

A-14 
Table A-4. Volatile Organic Compounds Analysis and Qualifier Summary. (sheet 1 of 2)

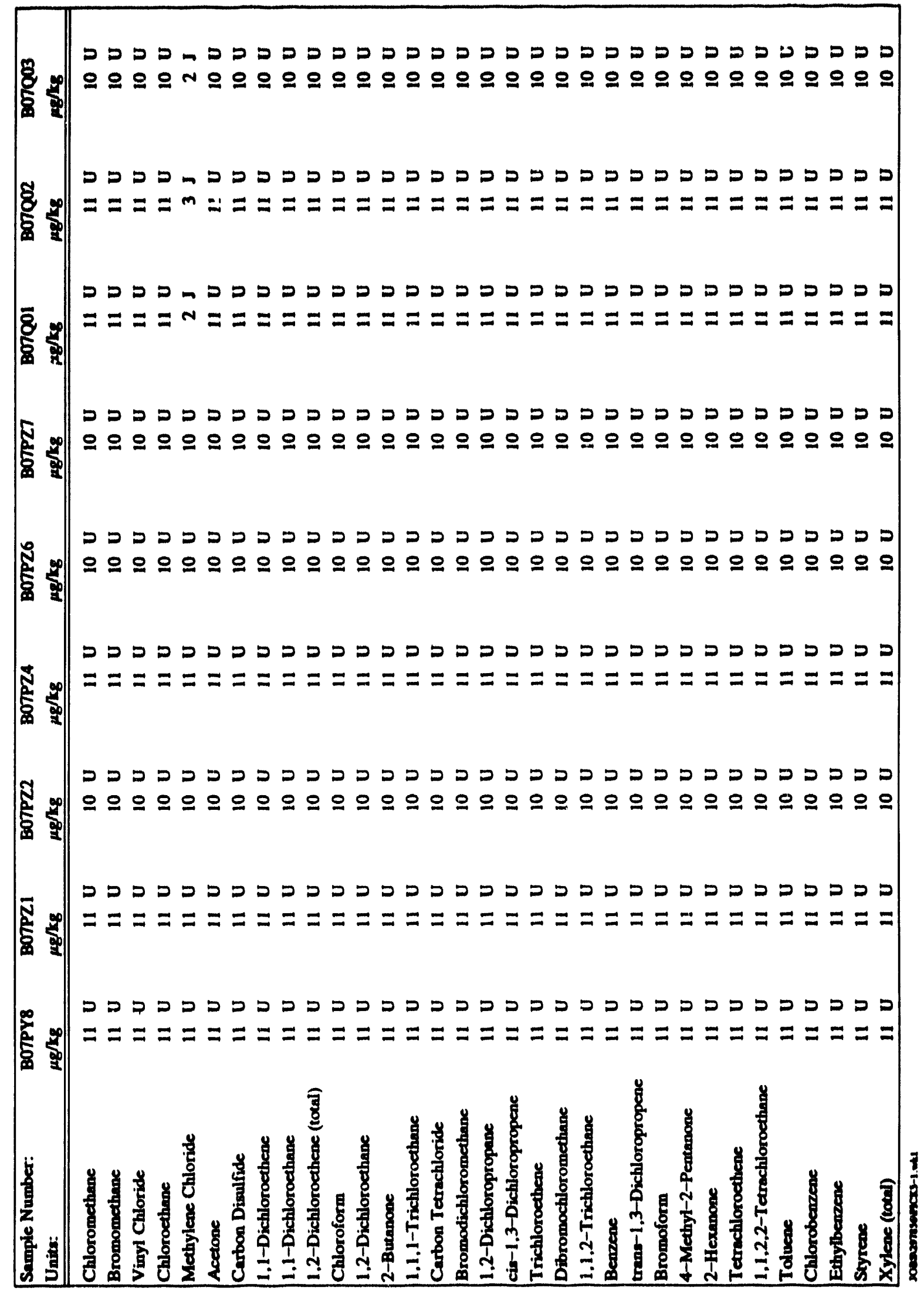


Table A-4. Volatile Organic Compounds Analysis and Qualifier Summary. (sheet 2 of 2)

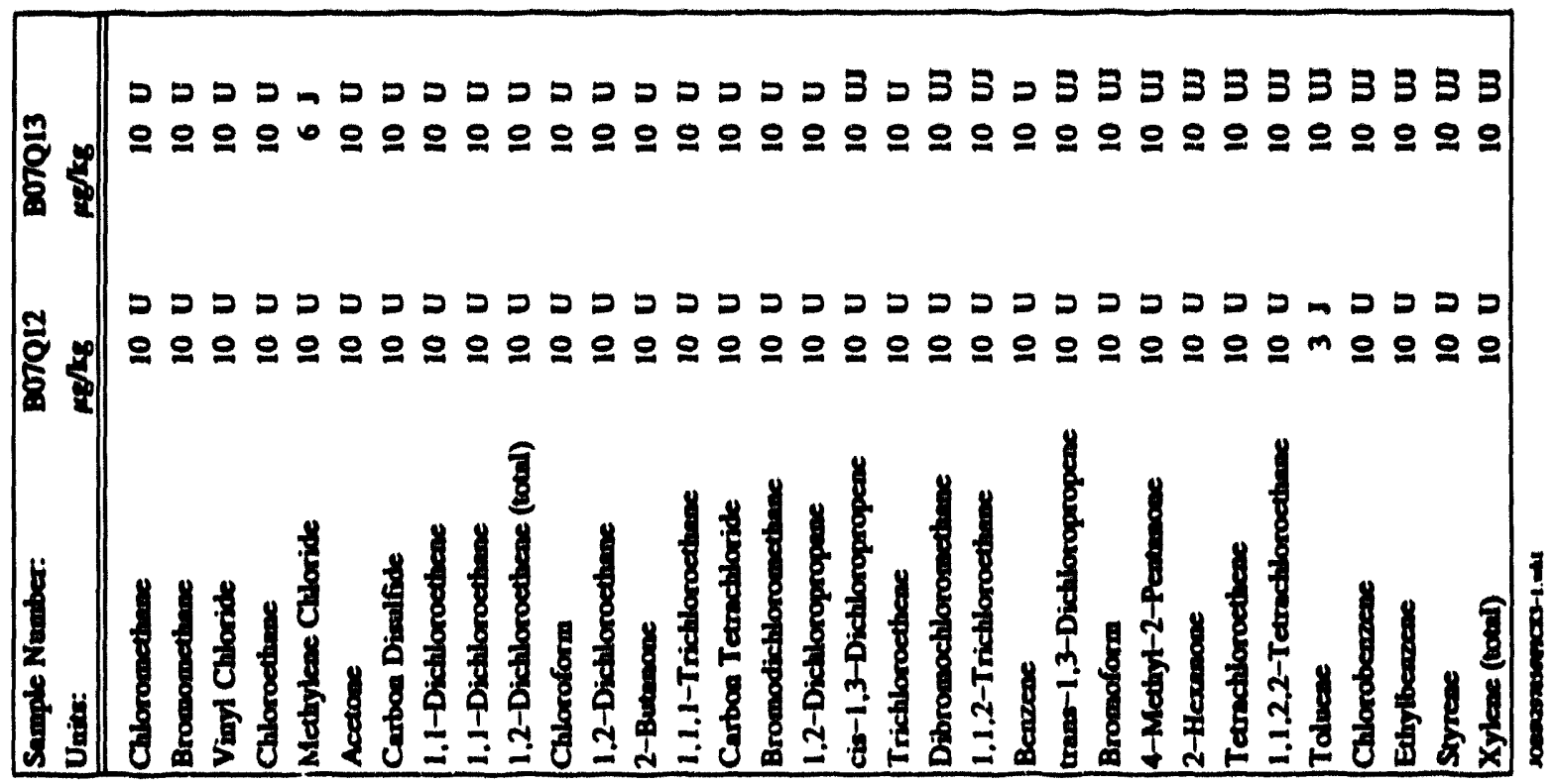


Table A-5. Semivolatile Organtc Compounds Analysis and Qualifier Summary. (sheet 1 of 6)

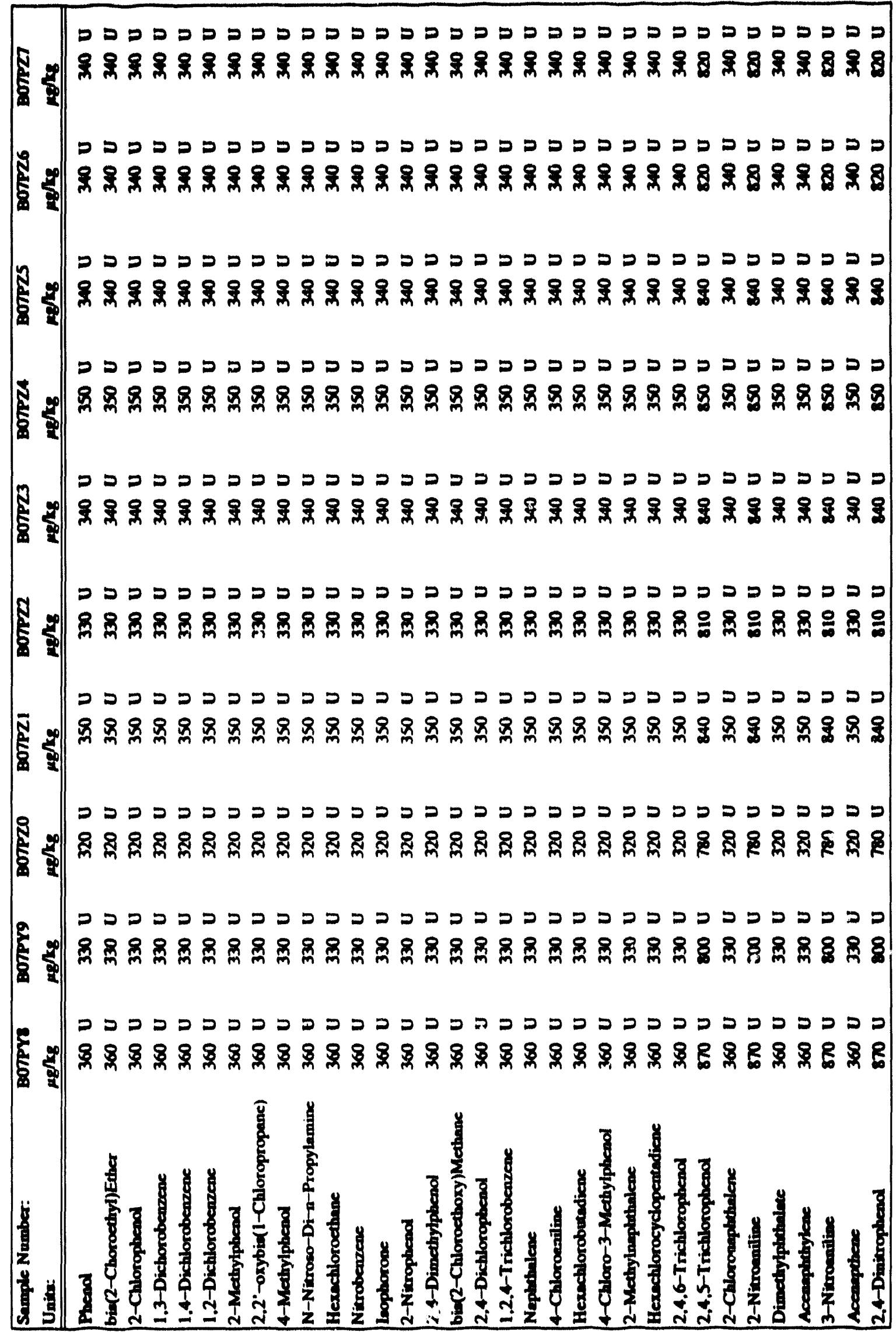


Table A-5. Semivolatile Organic Compounds Analysis and Qualifier Summary. (sheet 2 of 6 )

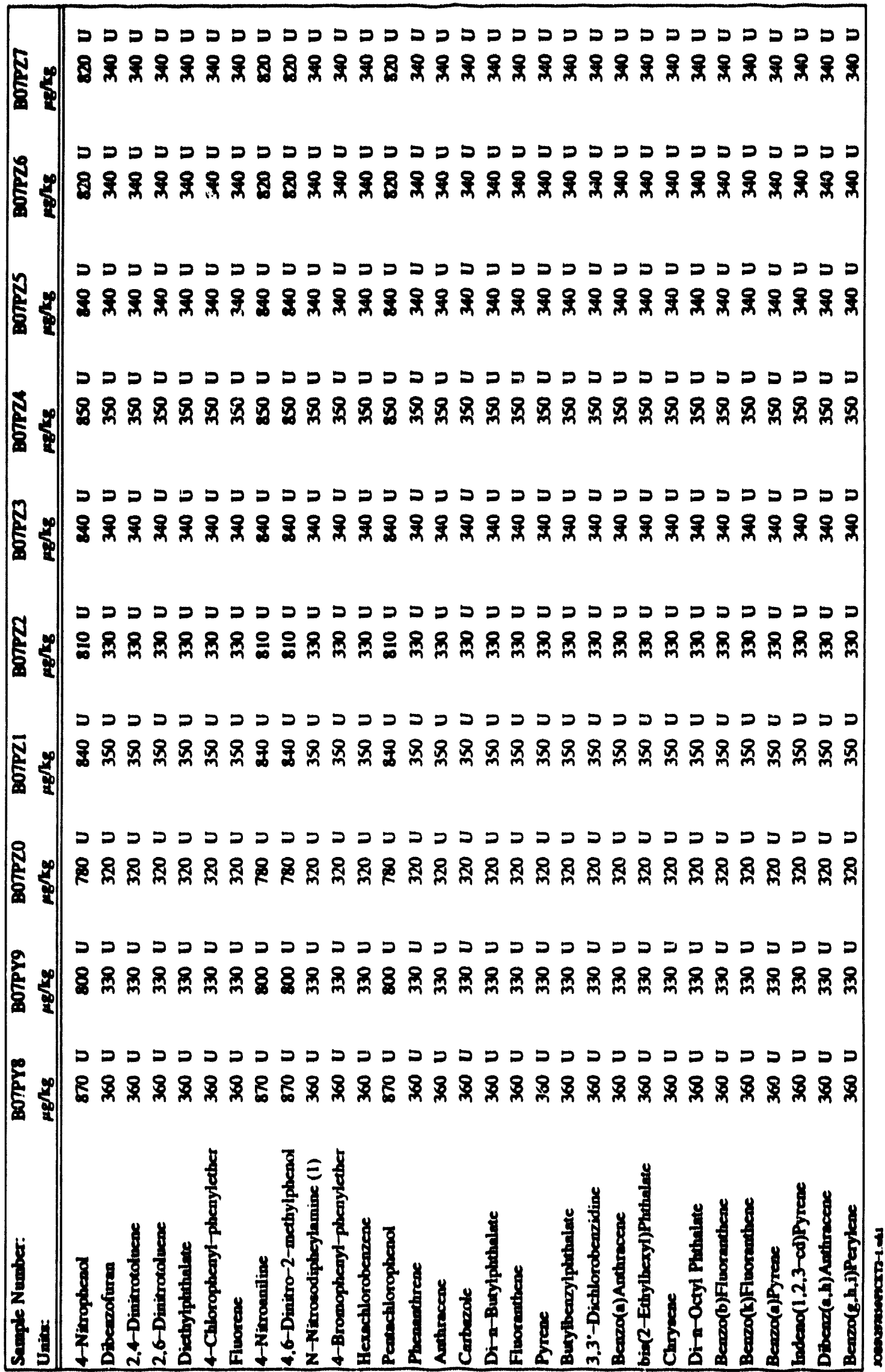


Table A-5. Semivolatile Organic Compounds Analysis and qualifier Summary. (sheet 3 of 6 )

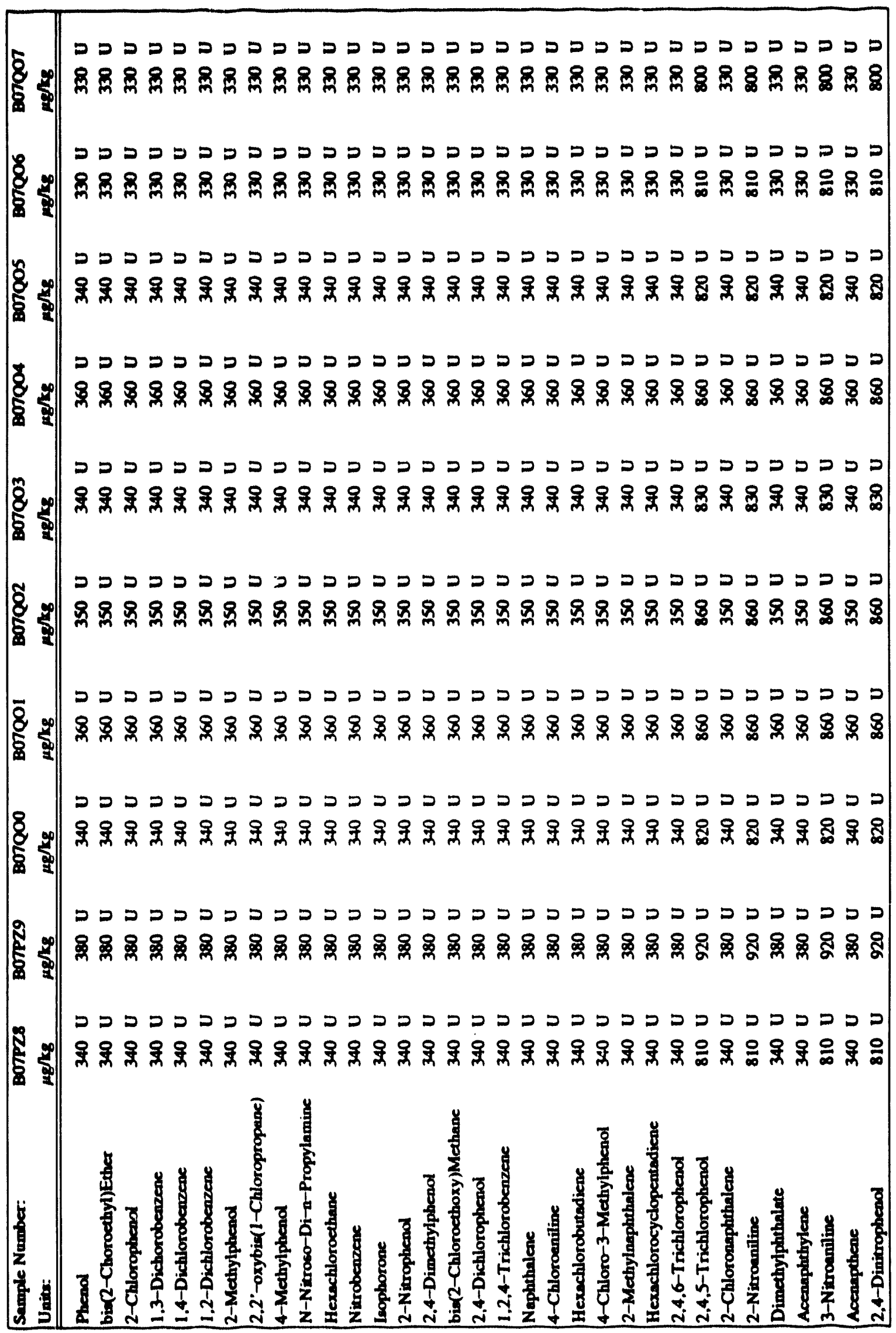


Table A-5. Semivolatile Organic Compounds Analysis and Qualifier Summary. (sheet 4 of 6 )

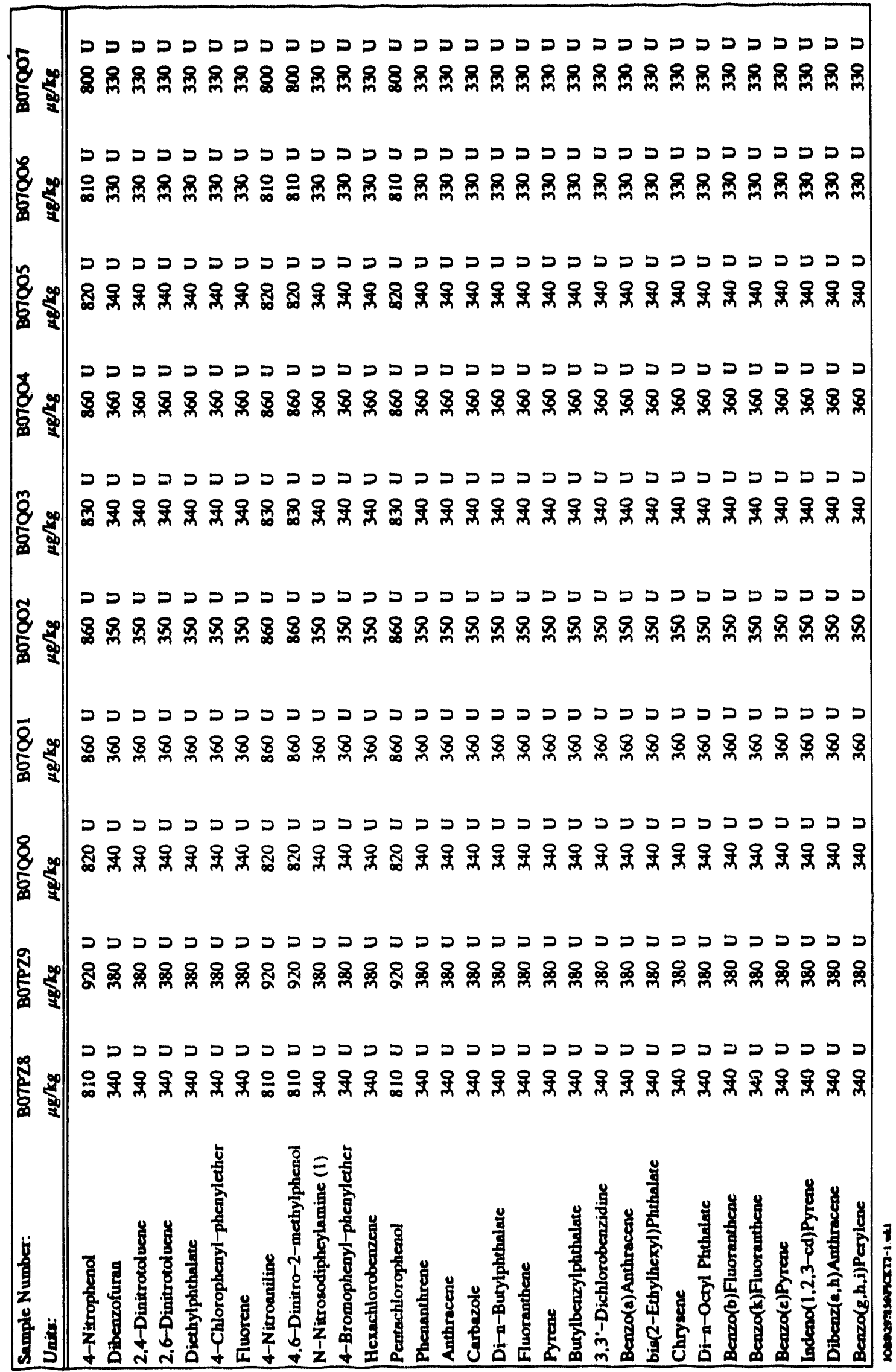


Table A-5. Semivolatile Organic Compounds Analysis and Qual ifier Summary. (sheet 5 of 6 )

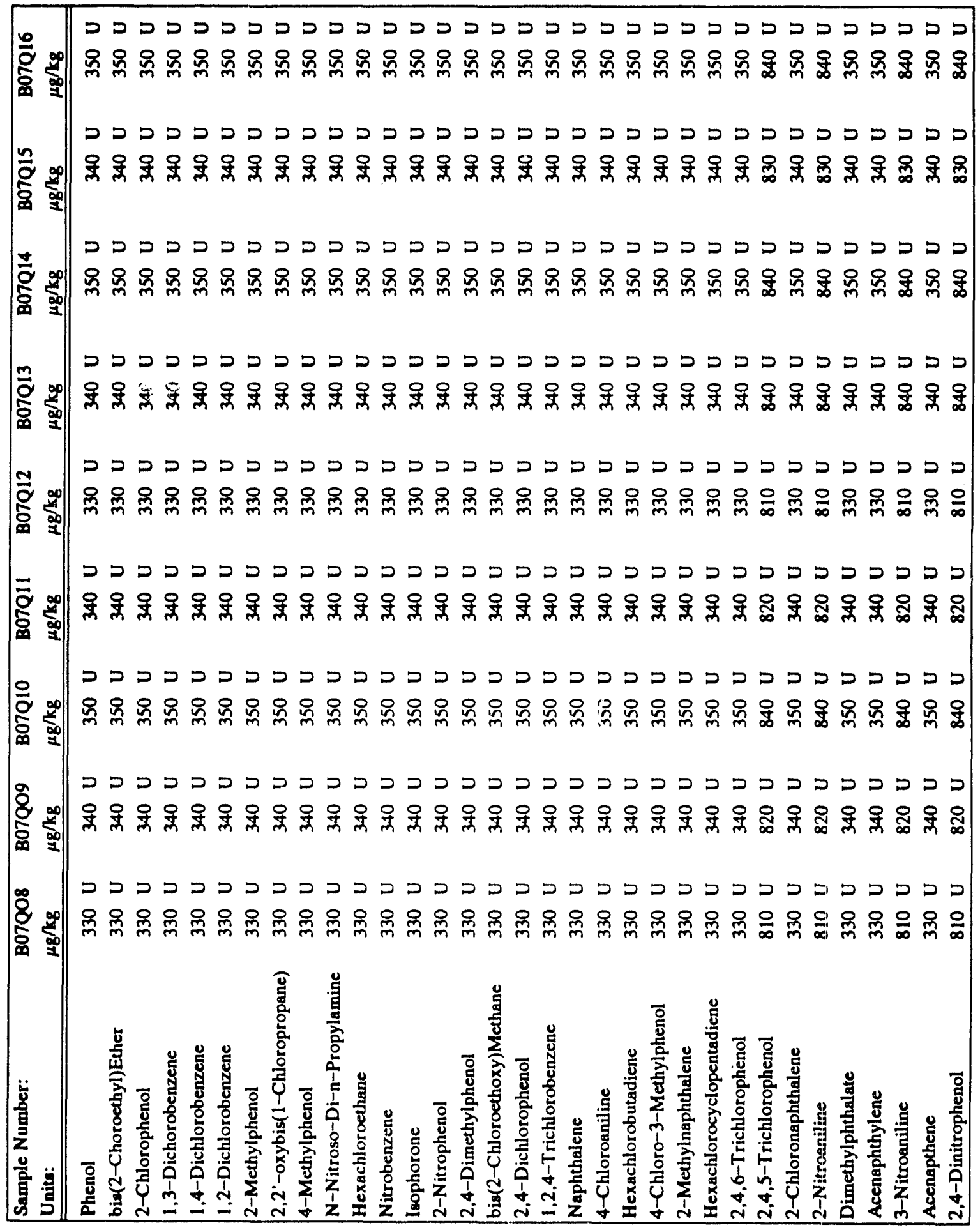


Table A-5. Semivolatile Organic Compounds Analysis and Qualifier Summary. (sheet 6 of 6 )

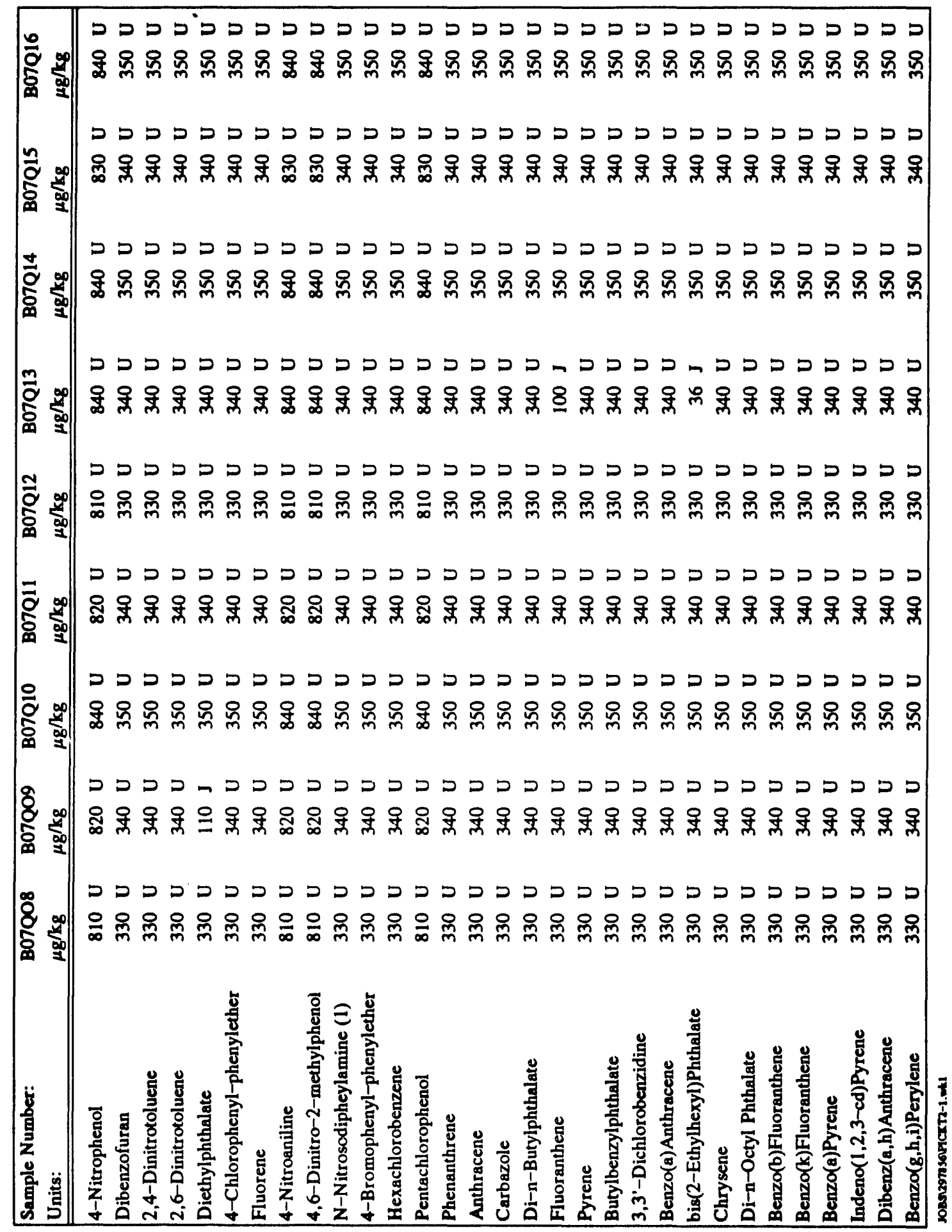


DOE/RL-93-48, Rev. 0

ATTACHMENT 1

JOINT LETTER FROM REGULATORS 

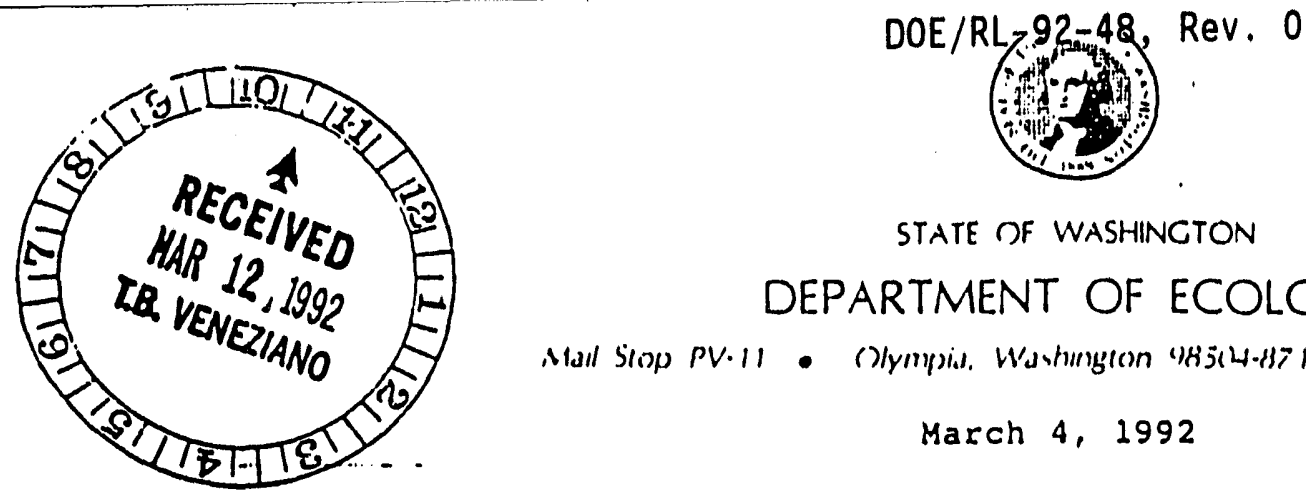

9201739

Attachment 1

STATE DF WASHINCTON

DEPARTMENT OF ECOLOGY

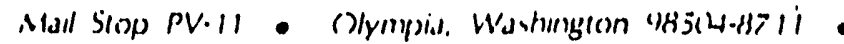

$(2(x)+59+5000$

March 4, 1992

Mr. Steven H. Wisness

Hanford Project Manager

U.S. Department of Energy

P.O. Box, 550 A5-19

Rlchland, WA 99352

Re: Expedited Responses Action Planning Proposals and Implementation

Dear Mr. Wisness:

On January 22, 1992, a meeting was held to discugs the selection of new Expedited Response Actions (ERA). The Washington state Department of Ecology (Ecology) and the U.S. Environmental Protection Agency (EPA) assumed the task of identifying candidate sites for planning proposal preparation, and identification of lead regulatory agency.

The primary reasons to perform ERAs are to minimize or eliminate the potential for release of hazardous substances and/or radionuclides in the environment and to initiate actions consistent with anticipated remedy selections. The final remedy selection would be made after completion of a Remedial Investigation/Feasibility study (RI/FS) or a RCRA Facility Investigation/ Corrective Measures study (RFI/CMS).

On December 12, 1991, a meeting was held to discuss selection of new ERAs. In this meeting, the U.S. Department of Energy (DOE) and Westinghouse Hanford Company (WHC) provided EPA and Ecology with a list of twenty-two (22) candidate sites. In addition, DOE and WHC were seeking approval to proceed with EE/CA preparation SOr the 300 Area Burial Grounds. Based on this meeting and a continuing dialogue between Ecology, EPA, DOE, and WHC, four (4) sites from the candidate list have been selected for planning proposal preparation. In addition, we request DOE submit planning proposals for two additional sites that were drafted previously for DOE, but as yet have not been submitted to Ecology and EPA.

Ecology and EPA prefer to delay initiation of an ERA on the 300 Area Burial Grounds. With the use of test pits in both the liquid disposal sites and the burial grounds, it appears the schedule for completion of RI/FS activities in 300-FF-1 may be accelerated. In addition, treatability tests planned for this year may identify appropriate means for remediating contaminated sediments from the liquid disposal sites as well as the burial grounds. Early completion of these investigations could result in a final Record of Decision for the 300-FF-1 Operable Unit earlier than projected. Ecology and EPA prefer 
Mr. Steve H. Wisness

March 4, 1992

Page 2

this course of action because it would potentially eliminate the need to. handle waste from the burial grounds twice (once as part of the ERA and again as part of the final remedy).

Ecology and EPA have selected the following four sites for planning proposal preparations:

Sodium Dichromate Barrel Disposal Landfill in 100-IU-4 Operable Unit

The sodium dichromate barrel disposal site in the 100-IU-4 Operable Unit was selected in part due because this is the only facility located within the 100-IU-4 Operable Unlt. Also, early remedial action at this operable unit may abate the potential of more extensive environmental degradation. Any ground water contamination from the sodium dichromate barrel site would be addressed as part of the 100-HR-3 Operable Unit. Removal of drums and contaminated sediments from this site may completely remediate the 100-IU-4 Operable Unit or may result in a no further action record of decision. This ERA would be designated as an Ecology lead site due to itg location within the 100-HR-3 ground water operable unit for which Ecology is also the lead regulatory agency. An ERA at the sodium dichromate barrel disposal site should not require extensive planning or characterization prior to initiation and therefore field work should begin in flscal year 1992.

\section{U.5. Bureau of Reclamation 2;4-D Burial site in 100-IU-3 Operable Unit}

The U.S. Bureau of Reclamation 2,4-D burial site in the 100-IU-3 Operable Unit was also selected in part because it is the only documented hazardous waste disposal area located north of the columbia River on the Hanford site. In addition, this site is one of the few waste sites where DOE does not control access. Removal of drums and contaminated sediments from this site could eliminate the primary source of hazardous waste from this part of the Hanford site and enhance public safety. The north slope area of the Hanford site has been of particular interest to Ecology due to public access and the existing lease agreement between DOE and the Washington state Department of Fish and Wildlife. Ecology would be designated lead regulatory agency for both this ERA and the 100-IU-3 operable Unit.

White Bluffs Pickling Acid Crib in 100-IU-5 Operable Unit

The white Bluffs pickling acid crib in the 100-IU-5 Operable Unit represents a significant source of acidic metal waste solution. This waste was generated from the final cleaning of reactor cooling pipes prior to installation in Hanford's eight single-pass reactors. These liquid disposal sites are located approximately one mile west of the 100-F Area near the old White Bluffs town site. Again, this gite represents the primary source of contamination within the 100-IU-5 Operable Unit and a removal action at this facility will likely limit 


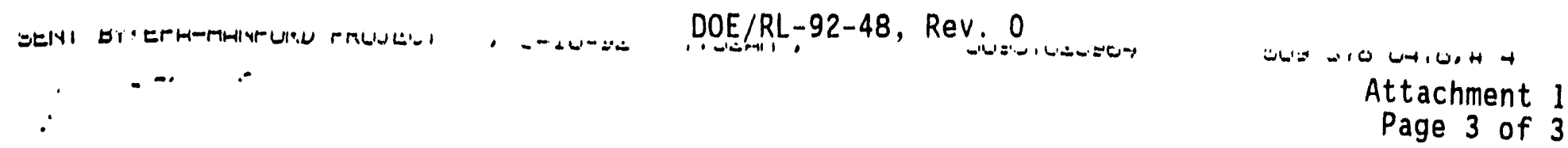

Mr. Stque 11. W1uneos

March 4, 1992

Pago 3

the need for and extenslve investlgation through an RI/FS. SLnce ILtLe 1. known about the axtent of contamination aspoolated with the Whita Bluffo plekling acld crlb, some degree of charactarleation will likely be requlred an part of an ERA at thls olte. Due to lto location upgradlent of 100-5 Area, EPA would be deslgnated as lead regulatory agency for both thlo ErA and the 100-IU-5 operable unlt.

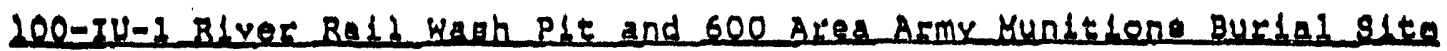

The 100-IU-1 oporable unle contalne two unlta. The rlverland ra11road car waoh pit was decontaminatod in 1963, and subseguantly raleaged from radlation zone otatus. Slte recorda indlcate that all ltema wero removed from the munttione burlal olta is 1986. Theso olteo are both located wort of Hlghway 240 and lack the acceas controla present at naarly all other past peactice iteo at Hantord. EPA w1ll be lead agency for thit ERA and the 100-IU-1 Operablo Undt. Thls presents the potentlal opportunity to reach a declalon to take no further action at an operable unlt after performlng a contlrmatory investigation. Wa expect that the ontire invertigation could be dono ag part of the ERA. If that is the care, the aRA would be tollowed by adminiatratlve ateps to rasch a Inat ROD.

Planning proposala for two addltional sltes are already drafted, but not releasod. These are for the 100 Area river outfald plpes and the $618-11$ busial ground. These plannling proposala should be transmleted to Ecology and EPA wlthout delay. The zegulatory lead agency wlld be ldentlfled for these proposals In the notlce to proceed with EE/CA preparation.

Should you have any guestions about the selection of eardidate alton for plannling proposal praparation or lmplementation, please contact alther steve Crose of Ecology (206) 459-6675 or Doug Sherwood of EPA (509) 376-9529.

sinceraly,
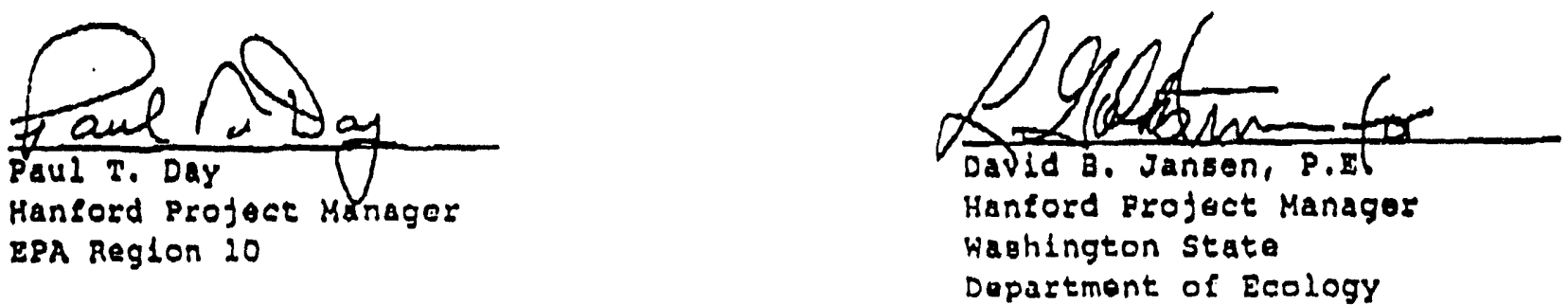

ce: T. Venordano, WHC 
DOE/RL-93-48, Rev. 0

DISTRIBUTION

Number of Copies

Onsite

31

U.S. Department of Energy, Richland Field Office

J. K. Erickson (30)

A5-19

Public Reading Room

Al -65

1

Pactfic Northwest Laboratory

Hanford Technical Library P8-55

38

Westinghouse Hanford Company

L. D. Arnold

B2-35

EDMC (7)

ERC (G. Fitzgibbon)

ERE (F. Stone) (2)

ERE Project File

ER Program Office (2)

H6- 08

$\mathrm{H} 6-07$

H6- 01

$\mathrm{H} 6-03$

J. M. Frain (20)

H6-27

IRA (3)

Resource Center

H6-04

$\mathrm{H} 4-17$

N3-05 

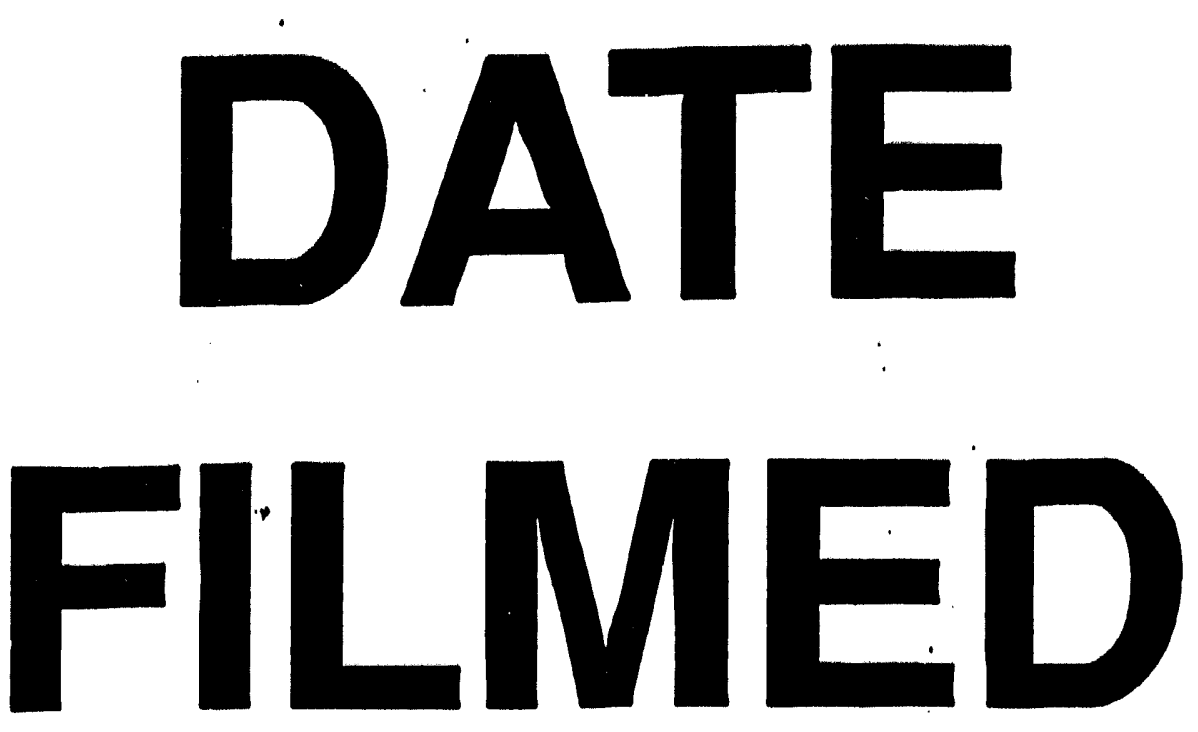

$12 / 10 / 93$
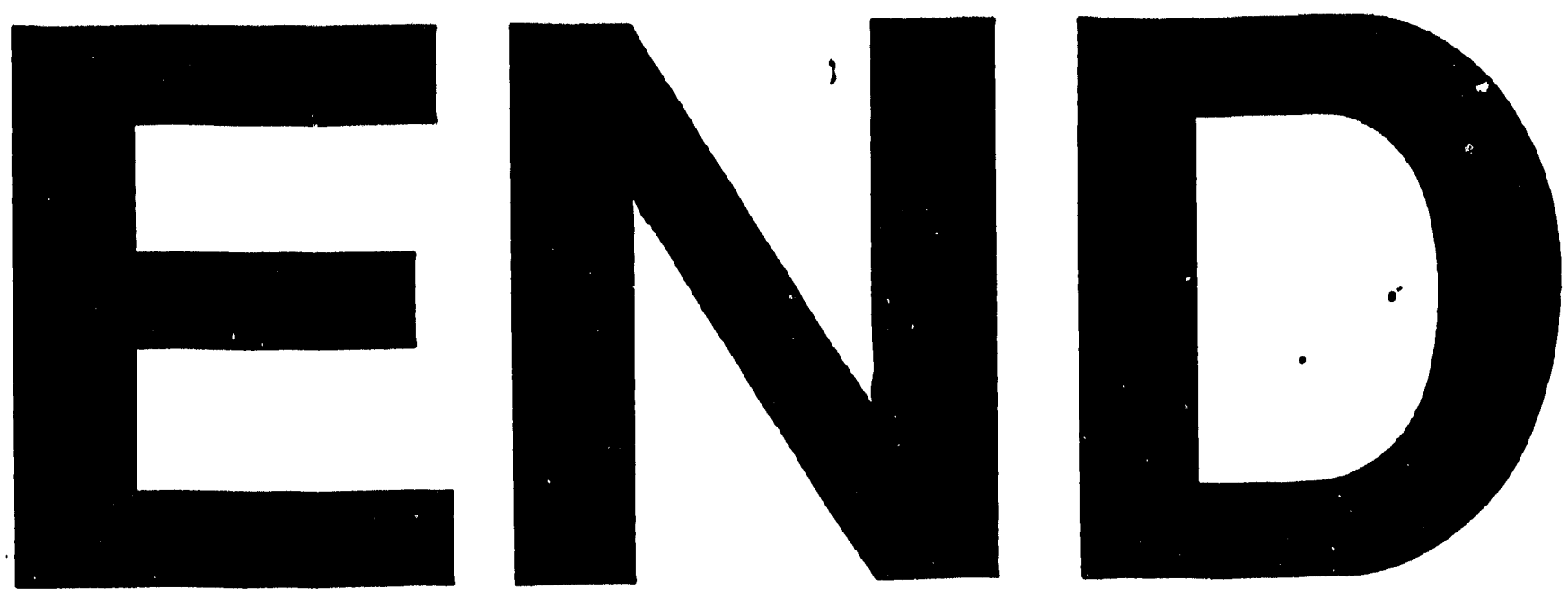
$$
-
$$

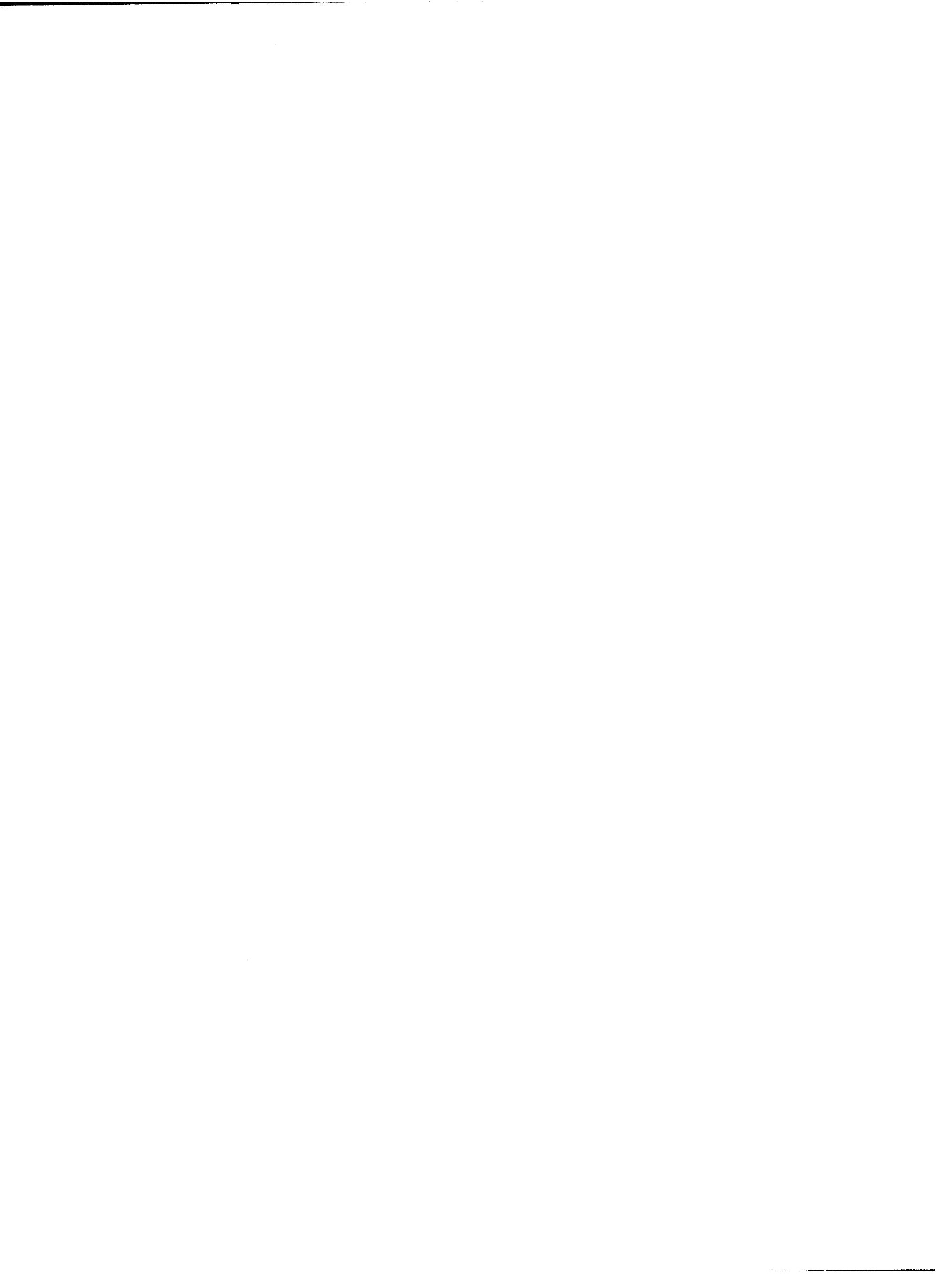

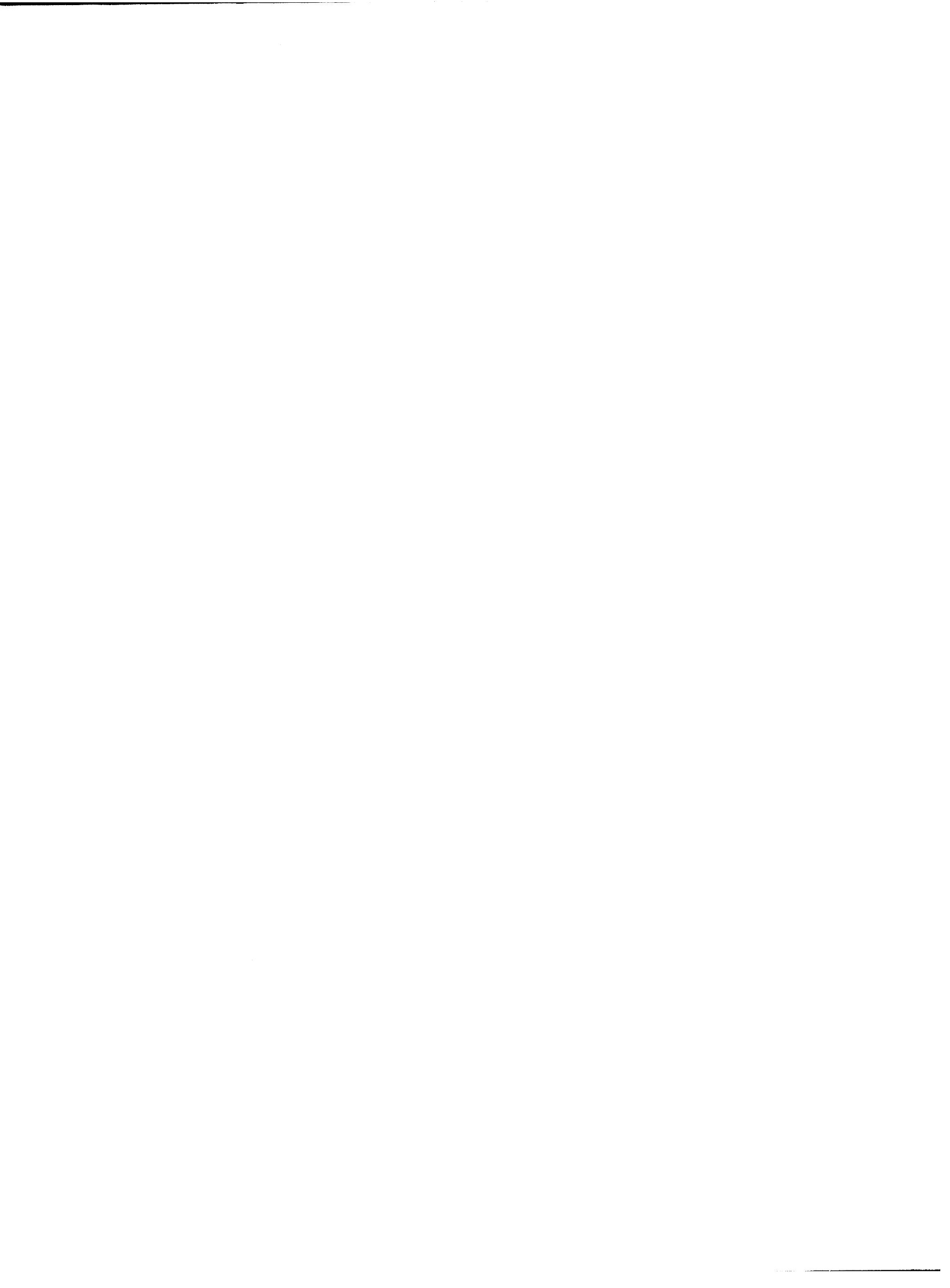

